\begin{tabular}{|c|c|c|c|}
\hline & $\begin{array}{l}\text { FATTiH } \\
\text { SULTAN } \\
\text { MEHMET } \\
\text { VAKIF ÜNivERSiTtesi }\end{array}$ & $\begin{array}{l}\text { FSM İlmî Araştırmalar Insan ve Toplum Bilimleri Dergisi } \\
\text { =SM Scholarly Studies Journal of Humanities and Social Sciences } \\
\text { Sayı/Number } 17 \text { Yıl/Year } 2021 \text { Bahar/Spring } \\
\text { (C)2021 Fatih Sultan Mehmet Vakıf Üniversitesi }\end{array}$ & 口 \\
\hline DOI: & & http://dergipark.org.tr/fsmia & http://dergi.fsm.edu.tr \\
\hline Araştırm & lesi / Research Article & Geliş Tarihi / Received: 01.03.2021 Kabul Tarihi / Accepted: 14.06.2021 & FSMIAD, 2021; (17): 481-512 \\
\hline
\end{tabular}

\title{
Tek Sözcük Döneminde Dil - Zihin İlişkisi, İki Dillilik ve İletişimdeki İşlevselliği (12. ve 13. Aylar) Muhammet Çelik*
}

\section{Öz}

İnsanda doğuştan var olan dil edinim süreci, anne karnında iken duyduğu seslerle başlar, ardından çeşitli safhalardan geçerek ortalama 12. ayda görülen tek sözcük dönemine ulaşır. Konuşmanın başlangıcı olan bu dönemde çocuğun, zihnindeki düşünceleri ifade etmek üzere kolayına gelen kelimelerden seçerek kullandığı tek tek kelimeler, çoğu kez sözedimsel bir güç taşır ve cümlelerin ifade ettiği anlamları barındırır. Dil ediniminin ilk safhalarından itibaren çocuklar, hayatın doğal akışı içinde birden fazla dili sorunsuzca edinebilirler. Çalışma, Türkiye'de sıklıkla görülen, Türkçe ve Kürtçeyi aynı anda edinen çocuklardan birinin örnekliğini yorumlamakta ve çocuğun kullandığ tek tek kelimelerden hareketle onun düşünce ve hayal dünyasına kapı aralamayı hedeflemektedir.

Anahtar Kelimeler: Çocuk gelişimi, tek sözcük dönemi, iki dillilik, dil - zihin ilişkisi, iletişim.

* Dr. Öğr. Üyesi, Fatih Sultan Mehmet Vakıf Üniversitesi İslami İlimler Fakültesi, İstanbul/ Türkiye, mcelik@fsm.edu.tr, orcid.org/0000-0003-0222-9784 


\title{
Linguistic Relationship, Bilingualism and Communication Function in the Single Word Period (The Twelfth and Thirteenth Months)
}

\begin{abstract}
The innate language acquisition process starts with the voices heard in the mother's womb, then passes through various stages and reaches the single word period around 12th month on average. In this period, which is the beginning of the conversation, the individual words that the child uses by choosing from easy words to express the thoughts in his mind often behave like a speech act and contain the meanings expressed by the sentences. From the early stages of language acquisition, children can easily acquire more than one language in the natural flow of life. This work interprets the example of one child who acquire both Turkish and Kurdish which is common in Turkey and aims to uncover his thoughts and imaginations based on the single words he uses.
\end{abstract}

Keywords: Child development, single word period, bilingualism, language-mind relationship, communication. 


\section{Giriş}

İnsanın doğumundan itibaren içinden geçtiği bilişsel gelişim safhaları tarih boyunca incelenmiş, bu incelemeler esnasında, farklı bakış açılarından hareketle farklı sonuçlara ulaşılmıştır. İnsan doğasına, insanın zihinsel yapısına ve dile dair yapılan araştırmalar her geçen gün ilerleyip daha karmaşık bir hal alırken, onun baştan itibaren içinden geçtiği bilişsel gelişim süreçlerine dair farklı teorilerden birini alıp yöntemsel zemine oturtmanın yanlış olacağ 1 da açığa çıkmış oluyor. Dolayısıyla Piaget' in biyolojik ilkeleri merkeze alan teorisi, Vygotsky'nin sosyal çevreyi öne çıkaran çalışmaları, Bruner'in yaşam boyu devam eden gelişim fikri ya da Gagne'nin öğrenme türleri tasnifi ${ }^{1}$ kendilerinden belli ölçülerde istifade edilecek araştırmalar olarak önümüzde duruyor. Kaldı ki bu yaklaşımların hiçbiri, ilgili bilim adamının mensup olduğu muhitten veya etkilendiği ideolojik yaklaşımdan ve bu yaklaşımın insana bakış açısından ayrı düşünülemez. Bu yüzden insanın bilişsel gelişimini incelerken biz onu mekanik bir varlık veya bir makine olarak gören yaklaşımlardan değil, aksine onu diğer canlılardan ayıran özellikleri öne çıkarmış yaklaşımlardan hareket etmeyi tercih ediyoruz. Dolayısıyla sanal zekânın veya bilgisayarın da belli ölçülerde "bilme" yeteneğiyle donatıldığ 1 günümüzde, insanı salt "bilen” olarak görmek onun kıymetini anlamamak olur, öyleyse doğumundan itibaren insana onun insan olmaklığ 1 bakımından yaklaşmamız gerektiği tezinden hareket ettiğimizi özellikle belirtmeliyiz.

Tek sözcük döneminin mahiyetine geçmeden önce, bu dönemin anadil ediniminin en önemli basamaklarından biri olduğunu belirterek başlayalım. Ayrıca burada "öğrenim" kelimesini değil de "edinim" kelimesini kullanmamız, bu sürecin doğallığıyla ilgilidir. ${ }^{2}$ Dil edinimine dair makale veya kitaplarda bu konudaki farklı yaklaşımların (davranışçı, sosyal etkileşim, psiko-linguistik vb.) ${ }^{3}$ hepsi say1lıp döküldüğü için burada böyle bir bilgilendirmeye ihtiyaç duymadan doğrudan konuya geçmeyi gerekli görüyoruz. Zaten bu tür yaklaşımları sürekli alternatifler olarak ileri sürmek de doğru değildir. Çünkü aralarında kronolojik ve birikimsel bir ilerleme de söz konusu aynı zamanda. Buna göre, mantıksal pozitivizmin etkisindeki yapısalcılık ve davranışçılığın, metafiziği bilimden kovma adına tüm zihinsel süreçleri dilbilimden ihraç etme şeklinde tezahür eden aşırı

1 Bkz: Suat Kol, "Erken Çocuklukta Bilişsel Gelişim ve Dil Gelişimi”, Sakarya Üniversitesi Ĕ̈itim Fakültesi Dergisi, say1 21, May1s 2011, s. 1-22.

2 Anadil edinimi ile yabancı dil öğrenimi arasındaki farklar için bkz: Murat Özüdoğru - Hakan Dilman, Anadil Edinimi ve Yabancı Dil Öğrenim Kuramları, Ankara, Anı Yayıncılık, 2014, s. 11; Şeref Kara, “Ana Dil Edinimi ve Erken Yaşta Yabancı Dil Öğretimi”, Uludağ Üniversitesi Eğitim Fakültesi Dergisi, cilt 17, sayı 2, 2004, s. 311. 
ideolojik yaklaşımlardan sonra, 1950-1960'lardan itibaren dil-zihin ilişkisinden hareketle geliştirilen teoriler bu önceki ideolojik yaklaşımların eksik ve hatalarını gözler önüne serdiği için, artık onları alternatifler olarak aktarmanın da bir anlamı olmasa gerek. İnsana özgü bir özellik olan dilin doğuştan getirilen bir yetenek olduğunda şüphe yoktur. Bununla birlikte dil gelişiminde sosyal çevrenin nasıl bir etkisi olduğuna dair araştırmalar 1970'lerden sonra hız kazanmış, günümüzde çok boyutlu yönüyle dil edinimine yönelik araştırmalar daha da artmıştır. ${ }^{4}$ Başka bir deyimle, burada kendi araştırmamızın ruhuyla uyumlu olan tezler üzerinden gidecek olmamız, hem tutarlı olmak hem de diğer tezlerle zaman kaybetmemek adına önemlidir.

Çocukta dil gelişimini inceleyenler, ondaki dilsel gelişim safhalarını "yenidoğan, agulama, mırıldanma, sesler çıkarma, tek sözcük kullanma" gibi safhalara bölmüşlerdir. İlk 28 günü yenidoğan, 2 ay ile 4 ay arasını agulama, 4 ay ile 6 ay arasını mırıldanma ya da cıvıldama, 6 ay ile 10 ay arasını heceleme veya bunlara benzer şekilde adlandıran dilciler, 12. ayın sonlarına doğru bebeğin ses-kelime safhasına geçtiğini söylüyorlar. Bebeğin bizim anlayabileceğimiz şekilde ilk "anlamlı" kelimeleri söyleyebilmesi hakkında kabaca 8 ay ile 18 ay arasına işaret edilmişse de daha ziyade ortalama olarak 12. ay civarı gösterilmiştir. ${ }^{5}$ Anlamlı kelimelerden maksat, çocuğun, söylediği sözcük ile onun delalet ettiği şey/nesne arasındaki irtibatı fark etmiş olarak konuşmasıdır. Yani daha önce "ba" hecesini tekrarlayarak tesadüfen "ba-ba" gibi bir kelime kullanıyorsa da onunla babasını kastetmiyordur. Bu gibi durumlar, konuşmaya başlamadan önceki ses alıştırmalarıdır. ${ }^{6}$ Çoğu dilde benzeri olan "baba, dede, anne, mama" gibi kelimelerin bebeklerdeki bu ses tekrarlarından alınarak kullanıldığını düşünebiliriz. Oysa tek sözcük dönemiyle birlikte çocuk çıkardığı ses ve telaffuz ettiği kelime ile neyi işaret ettiğinin farkındadır ve çevresindekilere de bunu fark ettirir. ${ }^{7}$ Bura-

4 Kronolojik bir değerlendirme için bkz: Emre Güvendir - I. Gamze Yıldız, Dil Edinimi, Ankara, Anı Yayıncılık, 2014, s. 11; Elvan Karacan, "Bebeklerde ve Çocuklarda Dil Gelişimi”, Klinik Psikiyatri, cilt 3, say1 4, 2000, s. 264; Gülçin Alpöge, "Çift Dilli Çocukların Dil Gelişimi", Turkophone, cilt 1, say1 1, 2014, s. 6.

5 Saadettin Keklik, Çocukta Dil Edinimi, Ankara, Türk Dil Kurumu Yayınları, 2015, s. 2127; Murat Özüdoğru - Hakan Dilman, a.g.e., s. 17; Turan Çakır, "Çocukta Dil Gelişimi ve Kuramsal Yaklaşımlar”, Sakarya Üniversitesi Eğitim Fakültesi Dergisi, cilt 0, sayı 7, 2013, s. 110-134.

$6 \mathrm{Bu}$ ses tekrarlarında semantik boyut eksik olabilir, daha sonraki konuşmalarda da fonetik eksiklikler olacaktır, bu da fonetik ve semantik gelişmenin nüve halindeki küçük boyutlarla birlikte başlayıp sarmal bir şekilde birbirlerini bütünleyerek ve besleyerek ilerlediklerini gösteriyor.

7 Bkz: Şenay Yapıcı, “Çocukta Dil Gelişimi”, Journal of Human Sciences, cilt 1, sayı 1, 2004, s. 9. 
da tek sözcük dönemi derken kastettiğimiz ve kendi gözlemlerimizden hareketle örneklendireceğimiz durum, sadece 12.-13. aylarla sınırlandırılacaktır. Çocukta doğuştan itibaren var olan dil özelliğinin ${ }^{8}$ bu merhalede aktifleşmesi ya da başka bir ifadeyle yetişkinlerle ortak bir zeminde buluşarak iletişimde işlevsel hale gelmesi, konuşmanın ya da bazılarının deyimiyle "gerçek konuşmanın" "başlangıcı kabul edilir. Ortak zeminde buluşmak demek, çocuğun kendi duydukları ile kendi üretimleri arasındaki çabası esnasında gitgide etrafindakilerle uyumlu bir müştereğe doğru meyletmesi demektir. Konuşmanın tanımı için birtakım kıstaslar belirleyip de 12 aylık çocuğu adeta -içinde yetişkinlerin de bulunduğu- "kim daha mükemmel konuşacak" yarışmasına sokmak anlamsızdır. Bu yüzden, kelimelerin kavramsal içeriğini yetişkinler kadar bilmese de, kelimeleri -yetişkinlere göre- "yanlış" telaffuz etse de, hatta kendi uydurduğu kelimeleri kullansa da, tek sözcük döneminde çocuğun konuşmaya başladığını kabul etmek zorundayız. ${ }^{10}$ Dil yeteneği insan zihninde hazır bulunduğuna göre, çocuğun "yanlışları" yoktur, kendi üretim ve kullanımları vardır sadece. ${ }^{11}$ Tek sözcük döneminden itibaren çocuk kendi kullanımlarını hem sesletme hem de anlatı düzeylerinde ${ }^{12}$ giderek sosyal çevresindeki kullanımlarla uyumlu hale getirmeye çalışır, eğer bunun tersini başarabilseydi bu da "doğru" bir dil olurdu şüphesiz. Çünkü kelimeler ile delalet ettiği şeyler arasında zorunlu bir irtibat yoktur, başka bir ifadeyle "anlamla ses arasında bağlant1 yoktur.”'13 Öyleyse Rousseau'nun da dikkat çektiği üzere, çocuğun eksik veya yanlış konuştuğunu zannetme hatasına düşmekten kaçınmak ve kelimelerin çocuk için taşıdığı gerçek anlama karşı ilgisiz kalmamak gerekir. ${ }^{14}$

Olaya yakından şahitlik etmeyen bazı insanlar çocuğa dili ebeveyninin öğrettiğini zannedebilirler. Oysa gerçekte olan şey, çocuğun dil yetisinin anne babasıyla iletişimi esnasında kendiliğinden geliştiğidir, tıpkı ayağa kalkıp yürüme

8 Noam Chomsky, Dilin Mimarisi, çev. İsa Kerem Bayırlı, İstanbul, Boğaziçi Üniversitesi Yay1nevi, 2014, s. 59-60.

9 Şenay Yapıcı, a.g.m., s. 8. Bu makalede "gerçek konuşma dönemi” üçe ayrılıyor: Tek kelimelik konuşma aşaması, iki kelimelik konuşma aşaması, gramere uygun konuşma aşaması.

10 B. Özbaydar, "12-24 Ay Arasında Dil Gelişmesi”, Psikoloji Çalışmaları, cilt 8, sayı 0, 2012, s. 80-81.

11 Bkz: Ayhan Aksu Koç - F. Nihan Kertez, “Anadili Gelişimi”, Aklın Çocuk Hali, (içinde), der. Çağla Aydın ve diğerleri, 3. bs., İstanbul, Koç Üniversitesi Yayınları, 2020, s. 14.

12 Anlamın da bireysel olmaktan ziyade toplumsal uygulamaların bir sonucu olduğuna dair tespitler hakkında bkz: John R. Searle, Bilinç ve Dil, çev. Muhittin Macit - Cüneyt Özpilavc1, 2. bs., İstanbul, Litera Yayınc1lik, 2016, s. 221-222.

13 J. V. Vendryes, Dil ve Düşünce, çev. Berke Vardar, İstanbul, Multilingual, 2001, s. 74.

14 Jean-Jacques Rousseau, Émile, çev. Yaşar Avunç, 9. bs., İstanbul, Türkiye İş Bankası Kültür Yayınlar1, 2017, s. 63. 
yetisinin gelişimi gibi. Chomsky’nin deyimiyle dil edinimi çocuğa öğretilen bir şey değil çocuğa olan bir şeydir. ${ }^{15}$ Doğal hayatın doğal bir parçası olan çevresel etkenler ise kullanılacak bu dilin hangi dil olacağı noktasında etkilidir. ${ }^{16}$ Dilin insanı hayvandan ayıran en önemli özelliklerden biri olduğu zaten bilinen bir gerçek olmakla birlikte çağımızda farklı bilimsel gelişmeler ile farklı deney ve gözlemlerden sonra bir kez daha ispatlanmış oldu. Bunu daha iyi anlamak için dilin ne olduğunu yeniden kavramak gerekir. Çünkü türümüze özgü olan ve "dil” diye adlandırdığımız şey, ağzımızdan çıkan sesler olmaktan ziyade, zihnimizde var olan bir şeydir ki "duymak, anlamak, düşünmek, anlamlandırmak, etkilenmek, kategorize etmek" gibi kısımlardan, sonra "zihnimizdekini ötekine aktarmakta araç kıldığımız ses veya hareket" türü şeylerden oluşur diyebiliriz. Bu özellik sayesinde insanın bu âlemde kendine özgü bir tarihi var olmuştur.

Araştırmalar dil gelişiminin çocuk doğmadan önce başladığını ortaya koymuştur. Yine anne adaylarının ceninle iletişim kurabildiğini gösteren araştırmalar da vardır. Bazı araştırmalara göre anne, karnındaki bebekle iki farklı dili aynı oranda konuşmuş, doğumdan sonra bebek her iki dile de aynı hassasiyeti göstermiş, hatta bu iki dili birbirinden ayırt edebildiğini göstermiştir. ${ }^{17}$ İnsan türü zihnindeki evrensel gramer ${ }^{18}$ yapısıyla birlikte dünyaya geldikten sonra, gelişiminin kritik döneminde iletişim halinde olduğu kişilerin dillerini bu yapıya uyarlar ve kendi iletişim dünyasını kurar. İlk bebeklik döneminde tüm dünya dillerine ait seslere duyarlı olan, ${ }^{19}$ hatta tüm dünya dillerine ait sesleri çıkarabilen bebek, zamanla anadiline ait sesleri daha sık duyduğu için onu edinmeye ve diğerlerini terk etmeye başlar. Buna göre, çocuklar hangi etnik kökenden gelirse gelsinler, gelişim döneminde iletişim halinde olduğu insanların dilini kolayca edinir, hatta bazen bu dönemde birden çok dili de edinebilirler. Piaget gibi çocuk psikologlarının da kabul ettiği üzere insan zihni

15 Noam Chomsky, Dilin Mimarisi, s. 20; Noam Chomsky, Bilgi Sorunları ve Dil: Managua Dersleri, çev. Veysel Kılıç, İstanbul, Bgst Yayınları, 2009, s. 159.

16 Emre Güvendir - I. Gamze Y1ldız, a.g.e., s. 23.

17 Mehmet Baştürk, Anadil Edinimi, 2. bs., Ankara, Pegem Akademi, 2013, s. 4; Mehmet Halit Atli, “Çokdillilik ve Çokdilli Beyin", Uluslararası Sosyal Araştırmalar Dergisi, cilt 11, sayı 60, 2018, s. 27.

18 Dilin insana özgü evrensel yapısı hakkındaki bilimsel tez ve gelişmeler hakkında daha geniş bilgi için bkz: Noam Chomsky, Dil ve Zihin Incelemelerinde Yeni Ufuklar, çev. F. Burak Aydar, İstanbul, Boğaziçi Üniversitesi Yayınevi, 2019, s. 27-28; Noam Chomsky, Dilin Mimarisi, s. 2930; Noam Chomsky, Bilgi Sorunları ve Dil, s. 81; Michael C. Corballis, İşaretten Konuşmaya Dilin Kökeni ve Gelişimi, çev. Aybek Görey, İstanbul, Kitap Yayınevi, 2003, s. 10-26.

19 Bekir Savaş, Okuma Eğitimi ve Çocuklarda Dil Gelişimi, İstanbul, Papatya Yayıncılık, 2018, s. 56. 
birden çok dili edinebilecek bir yapıya sahiptir. ${ }^{20}$ Dünyada çocukların üçte ikisinin iki dilli olduğuna dair araştırma sonuçları da bu gerçeği teyit ediyor. ${ }^{21}$ Üstelik bu edinme bizim kolayca gözleyemediğimiz erken bir dönemde başlayıp tek sözcük döneminden itibaren kendini bize aşikâr eder. Burada kelimeler dilin kendisi değil, tek sözcük dönemiyle birlikte bize yansıyan bir parçasıdır sadece.

$\mathrm{Bu}$ araştırmada söz konusu olan iki dillilik edinimi, her iki dilin aynı anda

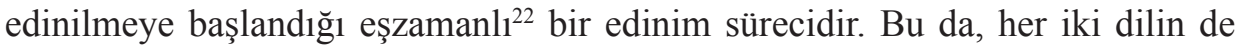
anadili sayıldığı anlamına gelir. Doğumundan itibaren eşzamanlı bir şekilde iki veya daha fazla dili birden edinen çocukların, beynin dil merkezi olan Broca bölgesindeki aynı ağı kullandıkları sonucuna ulaşılmıştır. ${ }^{23}$ Önceleri iki dilliliğin çocuktaki anadil edinimine olumsuz katkı yaptığına inanılıyor ve bu yönde yazılar yazılıyordu. Ancak araştırmalar ilerledikçe bu tezin yanlışlı̆ğ ortaya çıkmış, bunun tam aksine çocukların doğumdan itibaren hayatın doğallığg içinde iki veya daha fazla dili aynı anda öğrenebildiği ispatlanmıştır.

Tek sözcük dönemi diye yaygın şekilde kullanılan zaman diliminde çocuk düşündüklerini çoğu tek heceli olan kelimelerle karşı tarafa iletmek ister. Konuşma ile kelimeler arasındaki ilişkiyi inceleyen Vygotsky, çocuğun zihnindekileri dışa aktarmak istediğinde önce tek kelime ile işe başladığını, ardından iki ya da üç kelimeyi birbirine bağlayarak devam ettiğini hatırlatır. Dilin "konuşma" dediğimiz harici varlığı açısından sürece baktığımızda çocuğun parçadan bütüne doğru ilerlediğini görüyoruz, oysa dilin zihinsel olan dahili tarafi açısından baktığımızda çocuğun tek heceli bir kelimeyi söylerken bile -daha ilk baştan itibarenbelli bir cümleyle anlatılabilecek uzun bir düşünceyi aktarmak istediği görülür. ${ }^{24}$ Öyleyse tek sözcük döneminde ortaya çıkan şey, dilin kendisi değildir çünkü dil baştan beri vardır zaten; o halde bu dönemde ortaya çıkan şey, dil-zihin ilişkisinin konuşmaya yansıyarak fiziki dünyada aşikâr olmasıdır. İnsana insan olmaklığı bakımından yaklaşan bir bakış açısından hareket ettiğimiz bu araştırmada, onun kendine has bir özelliği olan dili merkeze almakla aynı zamanda onun zihnine yani düşünce dünyasına bir kapı aralamış olmayı hedefliyoruz.

20 Özüdoğru, Murat - Dilman, Hakan, a.g.e., s.21.

21 Bkz: Berna A. Uzundağ, - Aylin C. Küntay, “İkidillilik Gelişen Zihni Farklı Şekillendirir mi?”, Aklın Çocuk Hali, (içinde), der. Çağla Aydın ve diğerleri, 3. bs., İstanbul, Koç Üniversitesi Yayınlar1, 2020, s. 41.

22 Eşzamanlı dil edinimi kavramı için bkz: Emre Güvendir - I. Gamze Yıldız, a.g.e., s. 43. "Aynı anda dil öğrenimi” kavramı için bkz: Gülçin Alpöge, a.g.m., s. 8.

23 Mehmet Halit Atli, a.g.m., s. 230-231.

24 Yazarın düşünce ve sözcük arasındaki ilişkiyi incelediği bölüm için bkz: L.S. Vygotsky, Düşünce ve Dil, çev. Semih Koray, İstanbul, Kaynak Yayınları, 1985, s. 165 vd. 
Burada çocuğun 12. ve 13. aylarda iki dilli bir şekilde tek kelimeler aracılığıyla kendini ifade etme sürecini incelerken, bunun ebeveyn çevresindeki iletişimde nasıl bir işlevsellik gösterdiği üzerinde de duracağız. Ancak şunu belirtelim ki, iletişim derken burada özel bir tekniği veya özel bir tasarım veya ortamı değil, hayatın akışı içindeki doğal ilişkileri ve günlük yaşantıyı kastediyoruz.

$\mathrm{Bu}$ yazıda örnekleri kendi oğlum Hikmet Roni üzerinden verdim. Günlük yaşantı içinde var olan duruma herhangi bir müdahalede bulunmaksızın, onun 12 . ve 13. aylarda tek kelimelerle konuşmaya başlayışını hayatın doğal akışı içinde ve "var olduğu şekliyle" gözleyen bir tarama modelini kullandığımızı söyleyebiliriz. Annesi Hadice oğluyla konuşma dili olarak Kürtçeyi, ben de babası olarak Türkçeyi kullanmaktayız. Peki, gerçekten bu erken dönemde çocuğun kullandığg kelimelerden hareketle onun düşünce dünyasına bir kap1 aralanabilir mi? Buradan hareketle onda oluşmaya başlayan iki dilliliğin, nasıl bir dil-zihin ilişkisi oluşturduğu, çocuğun düşünce dünyasını nasıl yansıttığ1 yorumlanacaktır. Biz burada konuşmayı dilin sadece bir tarafı olarak ele alan yaklaşımımızla, birçok kitapta gördügüumüz "dil öncesi dönem" veya "dilimsi dönem” diye bir şeyin gerçekten var olup olmadığını sorgulayıp, aslında dil yeteneğiyle dünyaya gelen bir insanın böyle bir nitelemeyle değil de ancak "konuşma öncesi" şeklinde bir nitelemeyle belli bir dönemlendirmede konumlandırılabileceğini de göreceğiz. Son olarak araştırmamızdaki dilbilimsel yöntemin, betimlemeyle yetinen bir yöntem olmadığını, bunu aşarak açıklama ve yorumlamayla dilsel ifadeleri ele alan bir yöntem olduğunu belirterek konuya geçelim.

\section{Tek Sözcük Döneminde Tercih Edilen Kelimeler ve İki Dillilik}

Dilciler çocukların doğumlarından itibaren birden fazla dili sorunsuz olarak edinebileceklerini söylüyorlar. ${ }^{25}$ Araştırmalar iki dilli bebeklerin de dil gelişim safhalarını diğer bebeklerle aynı zamanda geçirdiğini ortaya koymaktadır. ${ }^{26}$ Ayrıca iki dilliliğin çocuktaki bilişsel esnekliğin gelişimine olumu katkıda bulunduğuna ve onun için bir kazanç olduğuna dair araştırmalar da mevcut. ${ }^{27} \mathrm{Bu}$ esneklik dilde ve düşüncede aynı anda gerçekleşir. Çocuk bir nesnenin ille de aynı kelimeyle karşılanmak zorunda olmadığını, bir nesne veya durumun birden çok sözle de karşılanabildiğini erkenden fark eder. Ayrıca benzer seslerin farklı

25 Solveig Chilla - Annette Fox-Boyer, İkidillilik/Çokdillilik, çev. Ezel Babur, Idstein, Schulz-Kirchner Verlag Gm, 2010, s. 15.

26 Berna A. Uzundağ - Aylin C. Küntay, a.g.m., s. 41.

27 Murat Özpolat - Mehmet Sağlam, "Erken Çocukluk Döneminde İki Dilliliğin Çocukların Alıc1 ve İfade Edici Dil Gelişimine Etkisinin İncelenmesi”, Erken Çocukluk Çalışmaları Dergisi, cilt 4, sayı 3, 2020, s. 791; Gülçin Alpöge, a.g.m., s. 9. 
dillerde farklı nesne veya durumlara karşılık gelebileceğini de görür. Böylece çeşitli boyutlarda ve yaratıcı düşünebilme yeteneği artar, kavram oluşturabilmede öne geçer. ${ }^{28}$ İki dilliliğin ayrıca üstdil yeteneklerini yani yüksek seviyedeki okuma-yazma kazanımı ile akademik başarıyı olumlu etkilediği de görülmüştür. ${ }^{29}$ İki dilli olarak yetişen bebeklerin kontrol mekanizması (sorun çözme, plan yapma, kendini kontrol etme vb.) açısından da diğerlerine göre daha iyi durumda olduğu söylenmektedir. ${ }^{30}$ Ancak biz burada Hikmet Roni'yi başka çocuklarla karşılaştırmayacağız, sadece onun kendi dil ediniminden söz edeceğiz.

Annesinin kendisiyle Kürtçe babasının Türkçe konuşması sebebiyle Hikmet Roni, tek sözcük döneminin 12. ve 13. aylarında her iki dilden de bazı kelimeleri öğrenip -telaffuz edebildiği kadarıyla- onları kullanmaya çalıştı. Bu şekilde kelimeleri biriktiren Hikmet Roni, daha sonra belli nesneleri veya durumları işaret etmek istediğinde veya belli bir konuda meramını anlatmak istediğinde, hangi dildeki kelime kolayına gelmişse onu almış ve kullanmaya başlamıştır. Örnek vermek gerekirse, Türkçe "yumurta" ve Kürtçe "hêk" kelimelerinden ikincisi kolayına gelmiş ve artık onu kullanmaya başlamıştır. Yine Türkçe "at" (atmaktan emir) ve Kürtçe "bavêje" kelimelerinden ilki kolayına gelmiş ve onu kullanır olmuştur. Bu dönemde çocuk iki dilin her ikisini de anlıyor, fakat telaffuz olarak hangisindeki kelime kolayına geliyorsa onu söyleyerek meramını dile getiriyor. Yani ben "yumurta" dediğimde de anlıyor ancak ona "hêk" demeyi tercih ediyor, aynı şekilde annesi "bavêje" dediğinde de anlıyor ama "at" demeyi tercih ediyor. Bununla birlikte bir nesneyi veya durumu gösteren kelimeler her iki dilde de onun telaffuzuna kolay gelmişse, her ikisini de kullanabiliyor. Örneğin bu süreçte Türkçe "el" ve Kürtçe "dest" kelimelerinden her ikisini de alıp "el" ve "det" şeklinde kullandığını gördük. ${ }^{31}$

$\mathrm{Bu}$ çerçevede onun tercih edip kullandığı Türkçe kelimelere "at (at-, hayvan olan at), ak (ayak, ayakkabı), ok (oku-), an (anne), bap (baba), el, al, aç, tut" gibi kelimeleri ve yine tercih edip kullandığı Kürtçe kelimelere "af (av/su), hêk (yumurta), nok (nohut), det (dest/el), hat (geldi), xal (dayı), ket (düştü), nan (ekmek)" gibi kelimeleri örnek verebiliriz.

28 Gülçin Alpöge, a.g.m., s. 9-10.

29 Nağme Canan, “Okul Öncesi Dönem Çocuklarda İki Dilliliğin Zihin Kuramı Gelişimi Üzerine Etkisi”, (Yayımlanmamış Yüksek Lisans Tezi), Maltepe Üniversitesi Sosyal Bilimleri Enstitüsü, İstanbul, 2012, s. 25, 32.

30 Mehmet Halit Atli, a.g.m., s. 31.

31 Yazıda geçen bütün Kürtçe kelimeler için şu kaynağa bakabilirsiniz: Fevzi Karademir (ve diğerleri), Sözlük/ Ferheng: Kürtçe-Türkçe \& Türkçe-Kürtçe, Ankara, Türk Dil Kurumu Yayınları, 2014. 
Aslında iki dillilik diye adlandırılan durum, bir tanıma göre kişinin gündelik yaşamında iki dili kullanması, ${ }^{32}$ bir başka tanıma göre kişinin her iki dili de iletişimde etkin olarak kullanabilmesi ve her iki dilde de kendini ifade edebilmesidir. ${ }^{33}$ Başka bir ifadeyle çocuğun her iki dilde fonolojik, semantik, morfolojik, sözdizimsel ve pragmatik açılardan gelişmiş olması gerekir. ${ }^{34}$ Ancak burada tek sözcük dönemi denilen erken çocukluk çağında bunun mükemmel olmasını beklemek insafsızlık olur. Aynı şekilde bütün bu becerilerin hiç başlamadığını söylemek de, gözlenebilir olan bir durumu görmezden gelmek, var olanı inkâr etmek olur. Dolayısıyla bizimkine benzer ailelerde görüldüğü üzere çocuk bu erken dönemden itibaren her iki dili de anlamaya ve her iki dilden seçtiği kelimelerle kendini ifade etmeye çoktan başlamıştır. Bu da iletişimde her iki dili de aktif olarak kullanmaya başladığı anlamına gelir; dahası Kürtçe konuşanlarla sadece Kürtçe, Türkçe konuşanlarla sadece Türkçe konuşmayı tercih edip ikisini ayrı ayrı kullanması için çok bir zamana da ihtiyacı yok, iki ayrı ortamı da sık sık tecrübe etmesi bunu idrak edip uygulaması için yeterli olacaktır. Çünkü çocukların küçük yaşta iki dili edinebildiği ve ikisini ayrı tutabildiğine dair çalışmalar var, ${ }^{35}$ bunu kendi çevremizden de gözleyebiliyoruz.

Hikmet Roni'nin iletişimde tercih ettiği kelimelerden hareketle, 12. aydan itibaren iki dilli bir şekilde konuşmaya başladığı sonucuna ulaşabiliriz. Çünkü kendisi bu kelimeleri kendi biyolojik gelişimine paralel olacak şekilde telaffuz etmekte, anlamlandırmakta ve iletişimde belli bir bağlama oturtmaktadır. Morfolojik ve sözdizimsel kullanımlara henüz somut düzeyde geçmemiş olsa da, kullanımların arka planındaki anlam çocukla ilgilenen kişilerce anlaşıldığında bu boyutların bağlamdan kolayca çıkarılabileceği görülür. Yani "al”, "aldım”, "alsın" veya "almak istiyorum" gibi ifadelerin hepsini "al" kelimesiyle karşılaması şimdilik onun dilindeki morfolojik ve sözdizimsel boyutları yüzeysel yapıda değil derin yapıda aramamız gerektiğini gösteriyor.

\section{Tek Sözcük Döneminde Kelimenin Oluşumu ve Yapısı}

Dil ediniminin aşamalı bir şekilde oluştuğu bir gerçek. Bu durum, dilin seslerle başlayıp gittikçe karmaşıklaşan birtakım alt sistemlerden ve parçalardan oluşan kompleks yapısıyla ilgilidir. ${ }^{36}$ Evrensel bir dil yeteneğiyle doğan çocuğun ilk altı ayda dünya dillerindeki tüm sesleri çıkarabildiği, ancak daha sonra, yetiş-

32 Mehmet Halit Atli, a.g.m., s. 26.

33 Murat Özpolat - Mehmet Sağlam, a.g.m., s. 791.

34 Nağme Canan, a.g.e., s. 20.

35 Gülçin Alpöge, a.g.m., s. 9.

36 Bekir Savaş, a.g.e., s. 45. 
tiği çevredeki dilin seslerini pekiştirip diğerlerini gittikçe elediği için belli dile/ dillere yöneldiği gözlenmiştir. ${ }^{37} \mathrm{Bu}$ dönemde oluşan kelimelerin yapısı da işte bu durumla ilgilidir.

12. ve 13. aylarda kelimelerin Hikmet Roni'de ses-dil-zihin ilişkisini tamamlayarak aktif kullanıma geçmesi, belli bir nesne veya durum ile belli bir kelimenin eşleşmesinden sonra gerçekleşti. Örneğin bir nesne yere düştüğünde annesi "ket" (düştü) diye seslenmişti, bunu kavrayan çocuk o nesneyi eline alıp tekrar düşürdü ve vurgulu bir şekilde "ket" diye seslendi. Bu seslenme, kelimenin ses düzeyinde var oluşu demekti. Buradaki vurgu o kelimeyi öğrenmesinden kaynaklanan heyecanın dışa yansımasıydı. Bu eşleştirme ve bu heyecan neticesinde o kelimeyi sık sık kullanmaya devam eden Hikmet Roni, "düştü” şeklindeki Türkçe fiili de anlamakla birlikte şimdilik "ket"i kullanarak iletişimine devam ediyor. Bunun nedeni kendi fizyolojisi açısından "ket"in "düştü"den daha kolay olmasıdır. Ve yine hikâye kitabında el ele tutuşma resmi geldiğinde elini tutup "tut" dememiz, onda bu kelimenin oluşmasına sebep oldu. Böylece anlaşıllyor ki, kelimeler ile nesne veya durumlar arasındaki irtibatın kurulmas1, o kelimelerin daha kolay bir şekilde tedavüle girmesini sağlıyor.

Bu dönemde çocuğun tercih edip kendini ifade etmede aktif olarak kulland1ğ1 kelimeler, telaffuzda onun fizyolojik gelişimine ${ }^{38}$ uygun olan kelimeler veya belli kelimelerin içinden alınmış ve bu fizyolojiye müsait olan parçalardır. Çocuk gelişimini araştıranlar, 12. ayda çocuğun sesli harflerin büyük bir kısmını ve birçok sessiz harfi kullanabildiğini ifade ediyorlar. ${ }^{39} \mathrm{Bu}$ çerçevede çocuk iletişimde kendisi için gerekli olan, ihtiyaç duyduğu kelimelerden ya da hoşuna giden, keyif aldığı kelimelerden kendi gelişmiş̧liğine uygun olarak belli yontumlar yapar ve kendi kelimesini oluşturur. Örneğin "anne" ve "baba" kelimeleri iletişimdeki işlevselliği açısından en çok kullanılanlar arasındadır. Bizde Hikmet Roni "an" ve "bap" şeklinde bu ihtiyacını karşıladı. Konuyu iletişimle bu denli irtibatlı kılmamız ilkin garipsenebilir. Ancak “çocuk 'anne' ve 'baba' kelimelerini mi yoksa kendi adını mı daha fazla duyuyor?" diye bir soru sorduğumuzda, ne demek istediğimiz daha iyi anlaşılacaktır. Evet, anne ve baba kelimelerini bizden duyarak kullanmış olabilir, ancak biz onun ismini çok daha fazla telaffuz ettiğimiz ve kendisi de bu ismi çok iyi bildiği halde, kendi adını seslendirmeye çalıştığını

37 Suat Kol, a.g.m., s. 14.

38 Türkçe anadili ediniminde çocukların ses bilgisel edinim sürecine dair bazı ayrıntılar için bkz: Seyhun Topbaş, "Sesbilgisi Açısından Dil Edinim Süreci”, Dilbilim Araştırmaları Dergisi, say1 7, 1996, s. 295-309.

39 Haluk Yavuzer, Çocuğunuzun İlk 6 Yılı, İstanbul, Remzi Kitabevi, 1997, s. 93. 
görmedik, çünkü iletişimde buna ihtiyacı yok. Fakat duvarda yazan "Hikmet Roni” yazısını gösterip okuduğumuzda bu hoşuna gitti ve bazen sorduğumuzda ya da kendi canı istediğinde onu gösterip kendi adlandırmasıyla "hit" diye k1saltarak bunu seslendiriyor. Diğer yandan "ta-ta" (tahta, yer sofrası) kelimesi günlük faaliyetlerinde çok da zorunlu olmayan bir kelime olduğu halde, gülerek tekrarlamasından anlıyoruz ki bunu öğrenip kullanmasının iletişimsel bir boyutu olmakla birlikte, hoşlanma, kendine duyduğu güven, bizi güldürmesinin kendini mutlu etmesi gibi farklı boyutları da bulunmaktadır.

Burada kelimelerin yontulması ya da bazılarının deyimiyle "sadeleştirilmesi" ${ }^{40}$, bazı seslerin daha kolay olanlarla değiştirilerek kelimenin "basitleştirilmesi" "41 ile birlikte, telaffuz edilebilir seslerin alınıp kelimenin kısaltılarak genellikle tek heceye ve bazen de iki heceye indirgenmesi sürecini ifade ediyor. Araştırmalar 18. aya kadar bebeklerin çok heceli kelimeleri de tek heceye indirgeyerek kullandığını, hatta iki yaşına kadar kullandığı kelimelerin yaklaşık \%70'inin tek heceden oluştuğunu gösteriyor. ${ }^{42}$ Örneğin Hikmet Roni, "saat", "rahat" ve "hatırlamak" kelimelerinin her üçünü de "at" şeklinde kısalttı. Tabi "rahat, hatırlamak" gibi soyut kelimeleri henüz tüm içeriğiyle birlikte kullandığını söylemek zor, ancak bizden duyunca hemen ardından tekrar etmesi, bizimle aynı bilişsel alana dahil olmaya ne kadar hevesli olduğunu gösteriyor. Yine "ayak" ve "ayakkabı" kelimelerini "ak" olarak, "şapka"yı ise kendinden bir " $h$ " ilavesiyle "hak" şeklinde kısaltıp aktif olarak kullandı. "Kulak" ve "kule" kelimelerinin her ikisini de "dul" olarak kısaltıp kullanıma sokması, yine fonetik gelişimle ilgili. Başka kelimelerinde " $\mathrm{k}$ " harfini kullanmasına rağmen burada üç harfli bir hecenin ilk harfinde "k" harfini "d"ye çevirdi. Tek boyutlu akademik düşünce kıskacından kurtularak farklı hikmetlere de kapı aralamak gerekirse, bu durumun anne babaya sevimli gelen, onları güldüren, mutlu eden, şefkatle dolduran başka bir boyutu daha olduğunu hatırlamamız yararlı olacaktır. Çünkü "dul” (L harfi ince) diye seslenmesi, "kule" veya "kul" diye seslenmesinden çok daha sevimli. Ve yine duvardaki adını gösterirken "Hikmet Roni"yi "hit" şeklinde kısaltması ya da "dest" (el) kelimesini “det" şeklinde kısaltması da bu fonetik-fizyolojik gelişmişliğe örnektir. Bu dönemde bazı hayvanları sesleriyle adlandırmak daha pratiktir; mesela köpek "hav", inek "mö" şeklinde ifade edilir, kapı zilini "lülülü” şeklinde seslendirmesi de buna dahil edilebilir. ${ }^{43}$ Bazı kelimelerin içindeki tek bir sesi alıp

40 Bkz: Haluk Yavuzer, a.g.e., s. 99.

41 Seyhun Topbaş, a.g.m., s. 296.

42 Elvan Karacan, a.g.m., s. 265; Turan Çakır, a.g.m., s. 122.

43 Bazılarının bu tür seslere "sembol" demesi gereksizdir, çünkü aynı hükmü dildeki tüm kelimelere verebiliriz. 
onu seslendirmek de bu dile dahildir, bu durumda tek hece değil tek bir harftir kullanılan. Örneğin "çay" için "ç" sesini birkaç kez tekrarlayarak "işte çay" gibi bir cümle kurmaktadır aslında. Ya da kitaplığın üzerindeki ney’i göstererek veya raftaki mumları işaret ederek dudaklarıyla üff üff (üfleme hareketi) yapması onların şimdilik bu şekilde adlandırılmasıdır.

\section{Tek Sözcük Döneminde Anlama-Dil İlişkisi}

Felsefede öteden beri insanın "hayvan-1 nâtık" olarak tanımlandığını ve bu özelliğiyle insanın diğer canlılardan ayrıldığını biliyoruz. Burada hayvan "canlı" anlamına gelirken, nâtık hem düşünen hem de konuşan anlamına gelir. Gazali'ye göre insanın cenin hali bile "nâtık" (düşünen) olarak nitelenmelidir; aksi halde ona insan denilemez. ${ }^{44}$ İnsan ancak "nutk" (düşünme/konuşma/logos) yoluyla varoluşunun tadına varır ve yine bu yolla gayesine doğru ilerler. ${ }^{45}$ Çünkü insan aklına özgü bir şey olan "nutk", insan nefsinin kendini anlamlandırıp ifade etmesidir. ${ }^{46}$ Söz dediğimiz şey, yani insanın konuşması, işte onun bu düşünme yeteneğinden ve aklî sezgisinden doğar. "Anlam" insan zihninde saklı kalıp sese dökülmedikçe "nutk" diye adlandırılır, fiziki dünyaya yansıyıp sese dönüştüğünde ona söz ya da konuşma deriz. İşte insana özgü olan şey budur ${ }^{47}$ ve bunu "mantık"48 kelimesiyle de irtibatlı olarak düşünmeliyiz. Çünkü insanın konuşması, diğer canlılar gibi ses çıkarması değil mantıklı düşünüp onu ifade etmesidir. Öyleyse insanın konuşması yani "nutk", dilinden çıkan seslerden ziyade onun zihnindeki anlamlardır, ancak bu anlamlar dilden de sadır olunca artık ona "nutk" demenin yanı sira bir de "söz/konuşma" (kelam) deriz. ${ }^{49}$ İşte tek sözcük döneminde (ortalama 12. ayda) çocuğun konuşmaya başladığını söylediğimizde, yaşanan hadiseye bu açıdan bakmalıyız. Bu durum Farabi'nin eskilerden aktardığ 1 "iç konuşma - dış konuşma" terimleriyle de ifade edilebilir. ${ }^{50}$ Çocuk biyolojik gelişimi elverir vermez iç konuşmasını (dahili nutk) dış konuşmaya (harici nutk) çevirebilmiştir. Başka bir ifadeyle, zihinde kuvve halinde bulunan dil, tek sözcük dönemiyle birlikte fiili

44 Ebu Hâmid Gazali, el-Me 'ârifu'l- 'akliyye, tahkik Abdulkerim Osman, Dımaşk, Dâru'l-Fikr, 1963, s. 27.

45 Ebu Hâmid Gazali, a.g.e., s. 35.

46 Ebu Hâmid Gazali, a.g.e., s. 42.

47 Ebu Hâmid Gazali, a.g.e., s. 54. Ayrıca bkz: Noam Chomsky, Bilgi Sorunları ve Dil, s. 16, 52; Noam Chomsky, Dilin Mimarisi, s. 18.

48 Bu irtibat hakkında bkz: İbrahim Emiroğlu, "Mantık", Türkiye Diyanet Vakfi İslâm Ansiklopedisi (DİA), cilt 28, İstanbul, TDV Yayınları, 2003, s. 18-28.

49 Ebu Hâmid Gazali, a.g.e., s. 63.

50 Ebu Nasr Farabi, İhsâu'l- 'ulûm, tahkik Osman M. Emin, Misır, Matbaatu's-Saade, 1931, s. 17. 
dile dönüşür. ${ }^{51}$ Buna ilaveten çocuğun tek kelimelik ifadelerinin de Chomsky'nin Port-Royal okulundan ilhamla geliştirdiği "derin yap1 - yüzey yapı" ${ }^{52}$ terimleri 1şığında yeniden anlaşılabileceğini söylemek mümkündür. Bu da bize, tek sözcük dönemindeki çocuğun ne söylediği (tek kelime) ile ne söylemek istediği (cümle veya cümleler) arasındaki ilişkiyi kurma imkânı vermektedir.

Dil ediniminin duyma ile başladığını, hatta bu durumun anne karnından itibaren gerçekleştiğini geride belirtmiştik. Aynı şekilde tek sözcük döneminde anlamak, konuşmaktan daima önce ve ondan çok daha gelişmiş bir şekilde mevcuttur. Başka bir ifadeyle onda "anlama" becerisi "anlatma" becerisini önceler. ${ }^{53}$ Burada anlamak ile konuşulan dili anlamayı kastediyoruz. Bu da dinleme yoluyla gerçekleşen dilsel bir eylemdir. Çünkü dinleme dediğimiz şey aslında "doğrudan doğruya dil aracılığıyla dış dünyayı anlama"nın bir yoludur. ${ }^{54}$ "Anlam" dediğimiz şey ise, "konuşanın dinleyene dil yoluyla ilettiği bir bilgidir." 55 "Alıcı dil - ifade edici dil" "56 şeklindeki tasnifi dikkate alırsak, anlama burada ilkine tekabül etmektedir. Semantik anlamın dışında sesleri anlama ve ayırt etme durumuna bakacak olursak; bebeklerdeki ses anlama ve ses ayırt etme yeteneğinin büyüklerinkine nispetle daha gelişmiş olduğunu görürüz. Araştırmalar bebeklerin ebeveynlerine yabancı olan farklı dillerdeki ses ve hece farklılıklarını bile ayırt edebildiklerini göstermektedir. Dil edinmede bebekleri yetişkinlere göre daha avantajlı kılan yetenek işte budur. ${ }^{57}$ Doğumdan önce bile var olduğu düşünülen bu yetenek, yeni doğmuş bebeklerin ebeveynin dilini/dillerini diğer dilden/dillerden ayırt edebilmesine yönelik araştırmalarla ${ }^{58}$ ve yine ilk dört veya altı ay içinde anadilleri ile ikinci bir dil arasında ünsüz sesler düzeyindeki farkları ayırt edebildiklerine dair

51 Bkz: Sadık Türker, "Fârâbî'de Dil ve Mantık İlişkisi”, Kutadgubilig Felsefe-Bilim Araştırmalarl, say1 1, 2002, s. 152.

52 Bkz: Noam Chomsky, Dil ve Zihin, çev. Ahmet Kocaman, 3. bs., Ankara, Bilgesu Yayıncılık, 2018, s. 44.

53 Haluk Yavuzer, a.g.e., s. 89; Saadettin Keklik, a.g.e., s. 28.

54 Murat Aşıc1, Ailede Dil Etkinlikleri, İstanbul, Morpa Kültür Yayınları, 2003, s. 27.

55 Ali Durusoy, "Mantık ve Dil”, Yakın Doğu Üniversitesi İslam Tetkikleri Merkezi Dergisi, yıl 6, cilt 6 , say1 1, 2020, s. 256.

56 A. Belgin Aksoy - Merve Aksoy, "Yürüme Döneminde Küçük Konuşmacılar: Gelişimsel Bir Bakış”, Erken Çocukluk Çalışmaları Dergisi, cilt 4, sayı 1, Mart 2020, s. 243.

57 Mehmet Halit Atli, a.g.m., s. 28.

58 Steven Pinker, Dil İçgüdüsü: Zihin Dili Nasıl Meydana Getirir, çev. Feray İlgün, İstanbul, Bilge Kültür Sanat, 2018, s. 299; Anthony J. DeCasper - William P. Fifer, “Of human bonding: Newborns prefer their mother's voices", Science, vol 208, issue 4448, 1980, p. 1174-6; Mehmet Halit Atli, a.g.m., s. 28. 
ulaşılan sonuçlarla da teyit edilmiştir. ${ }^{59}$ İletişimdeki karşl1ıklı anlaşmanın ise 8. aydan itibaren çok daha belirgin ve ilerlemiş bir hal aldığını söyleyebiliriz. ${ }^{60}$

Tek sözcük döneminde çocuk her ne kadar uzun cümlelerin yerini tutan tek kelimelerle meramını ifade ediyor ve henüz sözdizimini gerçekleştiremiyorsa da, uzun cümlelerle kendisine bir şeyler söyleyen kişiyi dinlediğinde onu rahatça anlaması, bu çocuğun sözdizimine dair bir fikre sahip olduğunu, bu süreçte sözdizimine dair birtakım zihinsel meşguliyetlerde, analizlerde bulunduğunu gösteriyor ${ }^{61}$ Hatta çocuğun bu dönemde "hı1?" gibi bir ses çıkararak nesneleri sormasına karşılık, ebeveynlerin sadece o nesnelerin adını vermekle yetinmemesi, o nesnelerin işlevlerine dair de bir şeyler söylemesi gerektiği söylenmektedir, çünkü bu dönemdeki çocuk -tam olarak anlamasa bile- o nesnelere dair daha açıklayıcı bir cevap beklemektedir.

Hikmet Roni hem annesinin Kürtçe konuşmasını hem de benim Türkçe konuşmamı anlıyor, kendini ifade etmeye sıra geldiğinde ise seçtiği kolay kelimeler ile bunu yapmayı tercih ediyor. Örneğin annesi "gözlerin nerede, ağzın nerede, kulakların nerede, saçların nerede, ellerin nerede, ayakların nerede" sorularını Kürtçe olarak sorduğunda çocuk bu organlarını işaret ederek kolayca cevap veriyor, aynı soruların Türkçesine de yine aynı kolaylıkla cevap veriyor. Konuşmaya gelince "el" için bazen "el" bazen "det" (dest) kelimelerini kullanıyor, "ayak" içinse "ak" kelimesini aktifleştirdi. Yine babaannesi ona Türkçe olarak "benim tespihimi getir" dediğinde, Hikmet Roni bu cümledeki kelimelerden hiçbirini telaffuz edemediği halde bu cümleyi anlayarak gidip tespihi getiriyor. Veya annesi Kürtçe olarak ona "git amcanın sana getirdiği arabayı al da gel" dediğinde bu cümledeki telaffuz edebildiği kelime olan "ap" (amca) kelimesini tekrarlayarak gidip o arabayı oyuncaklar içinden alıp getiriyor. "Anlama" ve "konuşma"yı hem dilin hem de zihnin iki asli unsuru olarak ele aldığımızda, bu örneklerden de anlaşıldığ 1 üzere, çocuğun her iki dile yönelik anlama maharetinin konuşma maharetinden çok daha geniş ve çok daha önde olduğunu görmekteyiz.

Bebeğin ilk iletişim dili olan "ağlamak" da dile dahildir aslında. ${ }^{62}$ Sonrasında işaret dilini kullanıyor çocuk..$^{63}$ Ancak dilin bu gibi farklı tezahürlerini atla-

59 Duygu Özge, "Çocuklarda Dil Anlama Süreçleri”, Aklın Çocuk Hali, (içinde), der. Çağla Aydın ve diğerleri, 3. bs., İstanbul, Koç Üniversitesi Yayınları, 2020, s. 68; Bekir Savaş, a.g.e., s. 61; Gülçin Alpöge, a.g.m., s. 6.

60 Elvan Karacan, a.g.m., s. 265.

61 Şenay Yapıcı, a.g.m., s. 11.

62 Murat Özüdoğru - Hakan Dilman, a.g.e., s. 18.

63 İşaret dili kullanımıyla ilgili ayrıntılar için bkz: Mehmet Baştürk, a.g.e., s. 6. 
yarak dilin -doğrudan- "konuşma" biçimindeki tezahürüne geçmek istiyoruz. Çünkü çocuklar dış dünyayı keşfetmeye devam ettikçe, iç dünyaları (düşünme ve duygu) ile dış dünya arasındaki irtibatı sıklaştırır ve diğer dillerin yanı sıra kendilerini kelimelerle de ifade etmek isterler. ${ }^{64}$ Böylece sesli konuşma, iletişim için en elverişli seçenek olması sebebiyle ${ }^{65}$ öne geçer ve merkezi bir konuma yerleşir. Bu süreçte nesneleri tanımaya başlayan bebek, mesela somut nesneler söz konusu olduğunda, bir nesneyi öncelikle zihniyle kavrar, zihninde o nesneye yönelik bir kavram oluşur, bu tamamen zihinseldir, ardından onu ya kendi başına ya da çevresinden duyduklarından hareketle seslendirip adlandırır, yani o kavra$\mathrm{m} 1$ dille ifade ederek ona doğrudan bağlı olmayan bir terime ulaşır. ${ }^{66}$ Başka bir ifadeyle zihindeki kavram sembolleştirilir. Eğer adlandırmak istediği kavrama delalet eden kelimeyi bulamaz veya telaffuz edemezse, onun için kendisi bir kelime uydurabilir. ${ }^{67} \mathrm{Bu}$, insanın adlandırma özelliğidir iște. Kur'ân'daki “ve Âdem'e bütün isimleri öğretti" 68 mealindeki ayeti de, dilciler "ona şeyleri isimlendirebilme yeteneği verdi, kavramlara isim vermeye onu kâdir kıldı" şeklinde anlamışlardır. ${ }^{69}$ Sesbirimlerden, kelimelerden ve cümlelerden oluşan dil, (işaret dili gibi) diğer dillere büyük oranda ihtiyaç bırakmayınca da asıl dil halini alır. Konuşma böylece başlar. Burada "konuşma" ile "dil" kavramlarını daha baştan ayırdığımız anlaşıldı sanırım. Konuşmak dilin sadece sese dökülmüş kısmıdır, dil henüz sese dökülmemiş olsa da zihinde var olan, tasarlanan, bir şekilde başkasına aktarılmak üzere bekleyen bir kısma da sahiptir. Dolayısıyla burada "anlama"yı takip eden şey, mantıklı düşünmedir ki, bu büyük ölçüde dil dediğimiz şeyle de kesişir. Konuşmak bu mantıklı düşünmenin mümkün mertebe sesletilmiş halidir çünkü. Sesletilemeyen düşünce belki resim veya müzik gibi sanatlarla karşıya aktarılmaya çalışılır ya da hiçbir şekilde aktarılamayıp bir süre sonra ölür, yani işlevsizleşir. Böylece tek sözcük döneminde çocuğun her iki dili de anladığını söyledikten sonra, nesneler arasındaki irtibatları kurup mantıklı düşünmeyi ${ }^{70} \mathrm{de}$

64 Bekir Savaş, a.g.e., s. 40.

65 Ali Durusoy, a.g.m., s. 256.

66 Abdulkuddûs Bingöl, "İletişim Bağlamında Mantık ve Dil”, Ankara Üniversitesi İlahiyat Fakültesi Dergisi, cilt XL, 1999, s. 107.

67 Turan Çakır, a.g.m., s. 117.

68 Bakara sûresi, 2/31.

69 Bkz: Ebu'l-Feth Osman İbn Cinnî, el-Hasâis, tahkik Muhammed Ali en-Neccâr, 3 cilt, Beyrut, el-Mektebetu'l-İlmiyye, 1952 (girişteki tarih), I, s. 40.

70 Burada mantıklı düşünme derken, onun yetişkinlerdeki ile aynı seviyede olmadığını söylemeye gerek yok sanırım. Yoksa çocuktan bir şey istediğimizde onu mantık diliyle değil sevgi diliyle isteriz bu dönemde. Örneğin çocuk dışarı çıkmayı seviyor ancak montunu giymek istemiyorsa bu dönemde bunu salt mantıkla izah etmek yerine konuşmanın yanı sıra asıl sevgi 
geliştirerek ileri bir boyuta taşıdığını ve ardından kendini ifade etmeye sıra geldiğinde bunu da fizyolojik gelişiminin elverdiği ölçüde çoğu tek heceden oluşan tek kelimelerle gerçekleştirdiğini söyleyebiliriz.

Dil-zihin ilişkisi ve dilin anlama dönük yanı, onun insana özgülüğü hakkında daha çok fikir veriyor. Yani daha ilk konuşma döneminden itibaren bir çocuğun dili, diğer canlıların iletişim sisteminden çok farklı. Düşünmeyi dilin bir parçası olarak görmediğimizde, zengin ses çeşitliliğine sahip bir kuşun dilini insanın diline yeğlemek gibi bir garabete düşebiliriz. Oysa mantıklı düşünmenin bir uzantısı olarak dil, insanı insan yapan şeylerden biridir. Burada örnek olarak Hikmet Roni'nin "dön” kelimesini vermek yerinde olacaktır. Kendi etrafında dönerek gerçekleştirdiği oyunu için benim "dön-" kelimesini kullandığımı gördükten ve bunu bir süre kullanıp pekiştirdikten sonra, oyuncağın tekerleği veya kalorifer s1caklık ayar düğmesi gibi dönen nesnelerle oynarken de zihninde kıyaslar yaparak kendiliğinden o kelimeler için de "dön” kelimesini kullanmaya başlaması, insana özgü dil özelliğini açıkça ortaya koyan en basit örneklerden biridir.

Aynı zamanda iletişimdeki işlevselliği açısından bakıldığında dilin bir "anlam taşıyıcısı" olduğu sonucuna varırız. ${ }^{71}$ Burada çocuğun söylediği kelimeleri herkesin anlayamaması, tıpk1 yabancı bir dili bilmeyen birinin o dili anlayamaması gibidir. Oysa bu safhadaki çocuğun dilini rahatlıkla anlayan anne babalar, onun sadece dilini anlamakla kalmaz, ihtiyaçlarını, hissettiklerini, hatta düşündüklerini bile belli bir ölçüye kadar anlayabilirler. Tam bu noktada, çocukların zihin dünyasını bu alanda yazıp çizen bilim adamlarından ziyade, çocuklarıyla yakından ilgilenen anne babaların daha iyi okuyabildiğini rahatlıkla söyleyebiliriz. $\mathrm{Bu}$ okumanın değeri, çocuk zihnine yönelik çalışmaların çocuğu/insanı nesneleştiren deneyci yaklaşımlardan ziyade ona hüsn-ü zanla yaklaşan ebeveyn güzellemelerine, belki de biraz şiirselliğe daha fazla ihtiyaç duyduğumuzu gösteriyor.

Mantıklı düşünme ile konuşma arasındaki ilişki beyin anatomisi ve sağl1ğıyla ilgili durumlardan da anlaşılabilir. Afazi diye adlandırılan dil ve konuşma bozukluğu, beynin sol tarafinda yer alan dil merkezindeki hasar sonrasında ortaya çıkıyor. Ancak bu hastalık kişinin sadece dil ve konuşmasını olumsuz etkilemekle kalmıyor, aynı zamanda mantıklı düşünmesini de olumsuz etkiliyor. $\mathrm{Bu}$ yüzden tıpçıların, dili "serebrumun özel alan ve bağlantıları tarafından ortaya konan düşünme ve iletişim için farklı şekillerde kullanılan sembollerden oluşan

diliyle sağlamak daha doğru olur. Nitekim sevgi dili ebeveynin hal ve hareketlerinden kendini ele verir. "Bebek ebeveyninin kalbinin derinliklerini görür, düşüncelerinin rengini fark eder." Bkz: Sefa Saygilı, Çocuk Psikolojisi, İstanbul, Nesil, 2018, s. 28.

71 Abdulkuddûs Bingöl, a.g.m., s. 107. 
kompleks ve dinamik bir süreçtir"72 şeklinde tanımlamış olmalarına şaşırmamak gerekir. Afazi türlerinin birçoğunda hasta kendini sözel olarak ifade edemediği gibi, karşısındakini anlama veya kendini başka bir dille (işaret dili, yazı vb.) ifade etme özelliklerini de yitiriyor. Örneğin böyle bir hastaya bir ihtiyacı olup olmadığını sorduğunuzda, eğer konuşamıyorsa bunu yazarak veya hareket diliyle anlatmasını beklersiniz ama yapamaz, çünkü hem sizi doğru anlayamaz hem de mantıklı düşünerek bunu karşıya aktarmayı başaramaz. Bu da dil ile düşünce arasındaki iç içe geçmişliği ve büyük orandaki kesişimi gösteren başka bir boyuttur.

Anlama ve düşünmenin seslerden oluşan bir sistemle dişa yansitılması sonrasında oluşan konuşma, tarihsel süreçte insanın hikâyesini oluşturarak ve birikerek ilerlediği için, büyük bir aktarım gücünü teşkil etmekte ve hayatın içindeki herhangi bir insanın dilinden başka zihinlere fikirler, duygular, imkânlar aktarmaktadır. Bu da dilin düşünceyi, düşüncenin de dili besleyerek sarmal şekilde insanı yeni imkânlara ulaştırdığını göstermektedir. Biz dil diye adlandırmasak da hayvanların da kendi aralarında kendilerince bir iletişimleri var, mesela bir kedinin yemek istediğinde çıkardığı ses ile yavrusunu çağırdığında çıkardığı ses farklıdır, yine bir köpeğin oynamak istediğinde çıkardığı ses ile saldırganlaştığında çıkardığ1 ses farklıdır, tecrübeli kişiler bunları ayırt eder. Ancak "dil-zihin ilişkisi”" burada da karşımıza çıkıyor diyebiliriz; çünkü hayvanların içsel dünyası ile iletişimde kullandıkları sistem arasında da niceliksel bir paralellik var, dolayısıyla sadece yetkin bir dilden değil aynı zamanda paylaşacakları üst düşünce yeteneklerinden de mahrum bırakılmışlardır.

\section{Tek Sözcük Döneminde Kelimelerin Kullanımı}

12-13 aylık bebeğin konuşması tek tek kelimelerden oluşur. Dilciler bu kelimelerden her birinin çoğu zaman bir veya birkaç cümleyi ifade etmek üzere kullanıldığında hemfikirdirler. Aynı kelimeyle birçok şey ifade edilmek istendiğinden, ilgili kelimenin ne anlama geldiği çocuğun o esnadaki durumuna bakılarak anlaşı1ır. ${ }^{73}$ Çocuğun günlük hayatındaki faaliyetleri, duyguları ve iletişim çabası çerçevesinde ilgili kelimenin ne anlama geldiği belli olur. Bu arada işaret dili de bu konuşmaya yardımcı olur. Telaffuz edilmeye başlanan kelimeler, benzer kelimelerin tedavüle girmesini kolaylaştırır. Böylece bu aylarda çocuğun birkaç kelimeden oluşan bir konuşma dünyası meydana gelir ki burada kelime sayısı çocuktan çocuğa değişebilir ve bu durum gayet normaldir.

72 Aktaran: Yahya Karaman - Fatih Bozbay, "Lisan Fonksiyonlarının Gelişimi ve Lisanı Etkileyebilecek Bozukluklar”, Erciyes Tip Dergisi, cilt 17, say1 1, 1995, s. 95.

73 Haluk Yavuzer, a.g.e., s. 98-99; Saadettin Keklik, a.g.e., s. 29. 


\section{İletişimdeki İşlevselliği}

Tek sözcük dönemi çocuğun tam da ayağa kalkıp yürümeye başladığı, dünyayı keşfetmeye koyulduğu, yetişkinlerle oyun oynamak istediği, tek kelimelerle konuşmaya ve iletişim kurmaya başladığ 1 bir dönemdir. ${ }^{74}$ Konuşmanın en önemli özelliklerinin başında onun iletişimdeki işlevselliği gelir. Nitekim tek sözcük döneminde çocuk konuşmaya başladı derken kastedilen şey, onun tek kelimeler aracılığıyla "derdini anlatmayı"75 başarmasıdır. Bu dönemde çocuğun konuşmasında isimler büyük bir yer tutsa da bunları salt isim olarak değerlendirmek yanlış olur. Aksine bu kelimelerle çocuk bir ricada bulunmakta, bir şeye itiraz etmekte, bir durumu haber vermekte ya da bir şey talep etmektedir. ${ }^{76}$ Çocuk tek sözcük döneminde kullandığı kelimeleri çoğu kez emir, istek ve dileklerini ifade etmek ${ }^{77}$ ve muhatabı bir eyleme sevk etmek üzere kullanır. Kelimelerini çoğunlukla emir anlamında kullanması, çocuğun "istikbal" olmasıyla, başka bir ifadeyle, onun tüm cehdiyle birlikte bir gelecek inşa etmeye yönelmesiyle ilgilidir. Çünkü bu dönemde çocuk tüm varlığıyla "yapmak, etmek, eylemek” kesilir adeta. Düşüncesi de, konuşması da, hareketleri de hep yapmaya yöneliktir. Bu arada yıkmalarını da bir tür inşa olarak almamız gerekir tabi. Ebeveyni peşinden koşturan bu olağanüstü dil aktifliği, bebeğin kelimeleri ardındaki anlamlar düzeyinde belagatte öteden beri "inşâ" 78 diye anılan, günümüzde Searle'ün "söz edimleri" (speech acts $)^{79}$ diye Türkçeye çevrilmiş kavramına ya da Austin'in Türkçeye "edimsel” 80 ve benzeri kavramlarla çevrilen "performative" terimine karşıllk gelen bir söz türünü barındırmaktadır. Bu durum bir anlamda iletişimin de çekirdeğini oluşturur. Searle'ün dediği gibi “iletişim, insanların eylemleri arasında kendine özgü bir eylemdir; çünkü dinleyici üzerinde niyet edilmiş bir etki oluşturmayı, dinleyicinin bu etkinin kendisini oluşturma niyetimizi bilmesini sağlamak suretiyle başarırız."

Elbette hayvanlar arasında da sosyal yaşamı benimsemiş türler vardır; ancak bir insan olarak dünyaya gelen canlı, diğer canlılardan farklı olarak kendi sosyalleşmesini sadece farklı davranış biçimleriyle değil aynı zamanda ve asıl

74 Sefa Saygill, a.g.e., s. 17-18.

75 Bekir Savaş, a.g.e., s. 46.

76 Şenay Yapıc1, a.g.m., s. 11.

77 Saadettin Keklik, a.g.e., s. 29.

78 Mesela bkz: el-Hatîb el-Kazvînî, Telhîsu'l-miftâh, Karaçi, Mektebetu'l-Buşrâ, 2010, s. 52.

79 Bkz: John R. Searle, Söz Edimleri, çev. Levent Aysever, Ankara, Ayraç, 2000.

80 Bkz: J. L. Austin, Söylemek ve Yapmak, çev. Levent Aysever, İstanbul, Metis, 2009, s. 41-45.

81 John R. Searle, Zihin Dil ve Toplum, çev. Alaattin Tural, 2. bs., İstanbul, Litera Yayınc1lık, 2015, s. 165 . 
olarak dil aracılığıyla sağlamaya yönelir. Mesela insan yeni bir şey öğrendiği zaman heyecanlanır ve bunu hemen başkalarıyla paylaşmak ister, bu durum onda bir konuşma isteği uyandırır. Aynı durumu tek sözcük dönemindeki çocukta da görebiliriz. Onun yeni öğrendiği bir şeyi, hayretler içinde ya da abartılı bir ses tonu ve mimikle size aktarmaya çalıştığını görürsünüz. Bunu tek bir kelimeyle yapar. Hatta çocuğun o esnada hayat tecrübelerini sizinle paylaştığını rahatlıkla söyleyebiliriz.

Bu çerçevede Hikmet Roni'nin 12 ve 13 aylıkken söylediği Kürtçe "af" (av/ su) kelimesini veya Türkçe "ak" (ayakkabı) kelimesini ele alalım mesela. Çocuk susadığında "af" diyerek bu ihtiyacını haber vermektedir. Kelimenin arkasındaki anlamsal yapı ilk başta bir haber cümlesi gibi gözükse de, aslında annesini veya babasını harekete geçirmesi sebebiyle bunun bir inşâ cümlesi, yani bir emir olduğunu düşünebiliriz. Aynı şekilde ayakkabıyı kısaltarak "ak" diyen bu çocuk, camiye gittiğinde orada çok sayıda ayakkabı olduğunu, hatta kocaman bir ayakkabılık bulunduğunu gördüğünde hayretini saklayamayıp "ak" diye tekrarlayarak koşturuyorsa, bunu da bir şaşırma/taaccub cümlesi olarak almamız mümkündür. $\mathrm{Bu}$ dönemde duygu ve düşüncelerini, yapmak ve yaptırmak istediklerini genelde olumlu cümle yerine geçen kelimelerle ifade eden çocuk, olumsuz cümle yerine geçecek kelime kullanmaya hiç de hevesli değildir. Bir şeyi istemediğinde bunu genellikle sızlanarak, ağlar gibi yaparak, yüzünü öteye çevirerek veya eliyle iterek ifade ediyor. Kelimelerinin ne anlama geldiğini içinde bulunduğumuz durumdan anladığımız çocuğumuzun bu dönemde söz konusu kelimeleri hep olumlu anlamda kullandığını gözlemledik. Ayrıca bu aylarda sınırlı sayıdaki birkaç kelimeyle konuşan çocuk, bu kelimeleri çok çeşitli anlamlarda ve çeşitli amaçlarda kullanmakla gün boyunca aktif bir iletişim ağı oluşturmakta ve küçük ama "zübde-i âlem" olan varlığıyla hayata bilfiil katılmaktadır.

$\mathrm{Bu}$ dönemdeki çocuğun dil edinimi, yetişkinlerin dil öğreniminden çok farklı olarak, hayatın akışı içindeki doğal iletişim sürecinde kendiliğinden oluşur. Bu yüzden mesela biz Hikmet Roni ile Türkçe ve Kürtçeyi iletişimde kullandığımız için o bu iki dili edinebiliyor, fakat Arapçayı -12. ve 13. aylarda- iletişimde pek kullanmayıp sadece bazen sesli çocuk şarkıları açarak ona dinlettiğimiz için bu dile dair kendisinde henüz bir edinim gerçekleşmedi. Ancak çevremizde gördügümüz örneklerde bu yaştan itibaren çocukların kendi gelişimlerine uygun çizgi filmler izlediklerinde oradaki görsele eşlik eden dilin iletişim esnasında kullanılması sebebiyle çocuklar tarafından edinilmeye başladığ1 ve bu dili konuşacak kişi bulurlarsa da bu edinimin gerçek anlamda gerçekleştiği görülmektedir. 


\section{Duygularını Dışa Taşırması}

Dilin konuşmaya dönüşmesi ille de doğrudan iletişimsel zorunluluklarla veya hayatın getirdiği ihtiyaçlarla ilgili olmak zorunda değildir. Başka bir ifadeyle, dil edinimi ille de çocuktaki "sorunları çözmeye yönelme"82 davranışıyla ilgili olmak zorunda değildir. Aksine çocuk keyif duyduğu için, eğlenmek için, ebeveynini güldürmek için ve daha birçok duygusal sebeplerle de konuşabilir. Bunların bir kısmı dolaylı olarak yine ihtiyaç gibi de görülebilir ve hatta iletişime kolaylıkla dahil edilebilir. Fakat burada diğerinden farklı olan şey, doğrudan ihtiyaç duymadığı halde çocuğun belli kelimeleri tekrarlayıp durması ve bundan keyif almasıdır. Monolog diye de adlandırılan ve çocuğun bazen yüksek sesle kendi kendine konuşması şeklinde tezahür eden durumlar, iletişimden bağımsız olarak onun haz aldığını, oyun oynadığını gösterir. ${ }^{83}$ Buradan hareketle dilin insanlar arası iletişim dışında da kullanılabilir olduğuna ulaşırız. Oyun oynama bunlardan sadece biridir. ${ }^{84}$ Nitekim ebeveynin oyun amacıyla kullandıkları bazı sesleri coşkuyla taklit etmesi ${ }^{85}$ de bunu göstermektedir.

Genellikle sevinç ve coşku durumlarında çocuğun iletişim amacı gütmeden belli bir kelimeyi kendi kendine tekrar edip durması, diğer oyunlarının yanı sıra, insan tabiatındaki sözlü sanat eğiliminin dışa yansıyan ilk belirtileri arasında sayılabilir. Düşüncesini tek bir kelimeyle ifade etmesi ona filozof dememizi gerektirmeyeceği gibi tek bir kelimeyi tekrar ederek sözel bir ritmi yakalaması da onu sanatçı diye adlandırmamızı gerekli kılmaz; ancak gerek büyük bir fikir adamı olma gerekse büyük bir sanatçı olma potansiyelinin onda çekirdek halinde mevcut olduğunu ve bu davranışlarıyla geleceğe 1şık çaktığını söylemek de yabana atılır bir iddia olmasa gerek. Söz konusu aylarda Hikmet Roni'nin "ta-ta" (tahta: yer sofrası) kelimesini neşeli anlarında tekrarlayarak kendince bir şarkıya dönüştürmesi onun duygularını dışa taşırması olarak yorumlanabilir. Çünkü bu kelimeyi böyle tekrarladığında ne bize bir şeyi haber vermek istiyor, ne de bizden bir şey talep ediyor, aksine kendisi keyif aldığı için bunu yapıyor. Tabi bu arada ebeveyninin orada bulunması da, şarkısını dinleyen birilerinin bulunmasını sağlamış ve onu daha da mutlu etmiş oluyor. Hayvanlar da bir sesi tekrarlayarak keyif alıyorlar, ritim tutturuyorlar belki, fakat insanın fark1, dili kullanarak bunu yapıyor olmasidir.

82 Piaget'in bu konudaki teorik yaklaşımı için bkz: Emre Güvendir - I. Gamze Yıldız, a.g.e., s. 14.

83 A. Belgin Aksoy - Merve Aksoy, a.g.m., s. 244.

84 Noam Chomsky, Bilgi Sorunlarl ve Dil, s. 51.

85 Haluk Yavuzer, a.g.e., s. 93. 


\section{Çocuğun Durumu, İşaret Dili, Ses Tonu ve Bağlam}

Çocuğun bu aşamada kullandığ 1 kelimelerle tam olarak neyi kastettiğini anlamak zor değildir. Çünkü kullandığ 1 kelimeleri çoğu kez belli bir ses tonuyla ve bazen buna jest ve mimiklerini de ekleyerek kullanır. Bu durumda çocuğun dil kullanımı tıpkı büyüklerdeki gibi inişli çıkışlı ses tonlarıyla gerçekleşir ${ }^{86}$ ve çoğu kez iletişime dönüktür. Bazen hoşlanmadığı bir şeyi asık bir yüzle veya yüksek bir ses tonuyla, hoşlandığ vurgulayarak söyler. Bazen tam tersine bir şeyden hoşlandığg için yüksek sesle coşkusunu dişa vurabilir. Çocukla ilgilenen kişiler onun ne zaman neyi kast ettiğini, ne hissettiğini anlarlar.

Önce ağlamayı, sonra işaret dilini kullanan çocuk, tek sözcük döneminde konuşmayı esas almasına rağmen işaret dilini de tamamen terk etmiyor. Hayatının sonuna kadar insanın bir ölçüde devam ettirdiği bu yardımcı dil, tek sözcük döneminde kelimeler ile nesneler ve durumlar arasındaki irtibatın sağlanmasında oldukça işlevseldir. Kaynaştırım diye adlandırılan bu durum, çocuğun kelimeleri "işaret, ses tonu ve jestler"le birlikte söyleyerek pekiştirmesi sürecidir. ${ }^{88}$

Hikmet Roni'nin kullandığı kelimelerden mesela yine "af” (av/su) kelimesini ele alalım. Bazen bu kelime "çok susadım, su istiyorum", bazen "suyla oynamak istiyorum", bazen de "işte orada su var" anlamında kullanılırken, kimi zaman da hiç susamadığ 1 veya suyla ilgili bir durum olmadığı halde sırf keyifli bir ritim tutturmak üzere tekrarlanır. Onunla birlikte yaşayan ebeveyn, onun hangi durumda neyi kastettiğini kolayca anlar. Burada ipucu olan şey, hem çocuğun o anki ruh hali hem ses tonu hem de hareketleridir. Aynı şekilde "bap" (baba) dediğinde, mesela bir keresinde asansör sesini duymuştur ve "babam geldi" demek istemiştir, böyle bir durumda ses tonu heyecanını dışa vurur, başka bir defasında "baba benimle top oyna" demek istemiştir, bu durumda da bir şey isteyen kişinin 1srarc1 ses tonunu onda hissederiz. "At" derken eliyle atma işareti yapması, "hêk" (yumurta) derken mutfağa yönelmesi ve benzeri durumlar, onun tıpkı çok hareketli bir hatip gibi, kendini ifade etmeye çalışırken bütün vücuduyla kendini hitabına verdiğini, heyecanlı ve aktif bir konuşma sürecine girdiğini gösteriyor.

\section{Kelimelerle Cümlelerin İfade Edilmesi}

Tek sözcük dönemi bir yana, ondan önceki agulama ve taklit-tekrarlama dönemlerinde bile çocuğun çıkardığı bütün seslerin tamamen anlamsız olduğunu

86 Haluk Yavuzer, a.g.e., s. 93; Bekir Savaş, a.g.e., s. 61-62.

87 Şenay Yapıc1, a.g.m., s. 11.

88 Şeref Kara, a.g.m., s. 301. 
söylemek zordur. Anne babaların "eminim konuşuyor ama ne söylediğini tam olarak anlamıyorum" 89 demesi şunu gösteriyor ki bu dönemde iletişim sözel olmaya henüz başlamamış, ancak sözün taklidine yönelen bir zihnin ilk alıştırmaları ve zihin-dil-konuşma birlikteliğini oluşturmak için dilin biyolojik hazırlığının ileri merhaleleri diyebileceğimiz bir durum başlamıştır. İşte tek sözcük dönemi bu dönemin hemen ardından gelerek sözel iletişimi doğrudan başlatır. Bu dönemle birlikte çocuklar tek kelimeler aracıllğıyla, yetişkinlerin bir veya birkaç cümleyle ifade ettikleri durumları anlatmayı başarırlar. Hatta bazen aynı kelimeyi farklı anlamları ifade etmek için de kullanabiliyorlar. ${ }^{90}$ Bunu dildeki eksiltili ifadelerin (hazf/ellipsis) erken bir örneği olarak da görebiliriz. Çünkü tek sözcük dönemindeki çocuğun biyolojik gelişmişliği, en az çaba kuralından istifade etmesini anlamlı k1lmaktadır. ${ }^{91}$ Burada -anlam açısından- cümlenin mahiyeti ile cümle yerine kullanılan tek kelimenin mahiyetinin aynı olduğunu iddia ediyoruz. Cürcânî’nin de işaret ettiği üzere, konuşan kişi birkaç kelimelik bir cümle söylediği zaman, onunla tek tek kelimelerin kendilerini kastetmez, aksine cümlenin ifade ettiği tek bir anlamı kasteder. ${ }^{92}$ Yani cümlelerle konuşmaya başlayan bir çocuk "baba beni parka götür" dediğinde burada dört kelime var olmasına rağmen birden çok anlam yoktur, aksine tek bir anlam vardır; çocuk burada babasının kendisini parka götürmesini istediğini ifade etmektedir. Aynı şekilde tek sözcük döneminde de Hikmet Roni "bap" (baba) dediğinde, bununla tek bir kelimeyi düşünmüş ya da tek o kelimeyi kastetmiş olmuyor, aksine yerine göre mesela "baba beni parka götür" veya "baba elindekini bana ver" gibi bir anlamı kastediyor. Buradan hareketle bizim burada 12-13 aylık çocuğun daha çok isim mi yoksa fiil mi kullandığına dair herhangi bir istatistik ortaya koymayışımız da anlaşılmıştır sanırım. Çünkü odaklandığımız mesele, isim de olsa fiil de olsa kullanılan kelimenin genellikle bir cümle ifade etmek üzere kullanılması meselesidir. Zaten dil edinimi de, çocuğun bütün kelime ve cümleleri zihninde depolama çalışması değildir, çünkü kelimeler sınırlı ama hem onlarla kurulabilecek cümleler ve hem de ifade edilebilecek anlamlar sınırsızdır. ${ }^{93}$ Aslında yetişkinlerin konuşmasında

89 Murat Özüdoğru - Hakan Dilman, a.g.e., s. 19.

90 Bekir Savaş, a.g.e., s. 61.

91 En az çaba kuralı şöyle tanımlanıyor: "Konuşma sırasında zamandan ve emekten tasarruf ederek kolaylık sağlamak amacıyla ses düşmesi, ses benzeşmesi, ses ve hece kaynaşması gibi olaylara yol açan kural.” Zeynep Korkmaz, Gramer Terimleri Sözlüğü, 2. bs., Ankara, Türk Dil Kurumu Yayınlar1, 2003, s. 84.

92 Abdulkahir Cürcânî, Delâilu'l-i 'câz, tahkik M. Muhammed Şakir, Kahire, Mektebetü'l-Hânci, 1984, s. 412-413.

93 Mehmet Baştürk, a.g.e., s. 2. 
da, belli bir niceliksel gelişmenin dışında, değişen çok fazla bir şey yok; çünkü -Chosmky'nin deyimiyle- herhangi bir doğal dili ele aldığınızda, onun sınırlı sesbirimlere/harflere sahip olduğunu ama buna rağmen o dilde sınırsız sayıda cümle oluşturulabildiğini görürsünüz..$^{4}$

Örneğin Hikmet Roni, tek heceden oluşan "at" kelimesini bizden alıp kullanmaya başladi. Bu kelimenin birçok anlama geldiğini fark etmesi uzun sürmedi ve çok geçmeden bu kelime gün içinde en fazla kullandığg sözlerden biri haline geldi. Bu kullanımlardan bir kısmı bizdeki tek bir kelimeyi karşılamaya yönelik iken, bir kısmı bizdeki bir cümleyi veya birkaç cümleyi karşılamaya yönelikti. Böylece günlük faaliyetlerinin birçoğunu bu ve buna benzer tek heceli kelimeleri kullanarak halletme yoluna gitti. "At"ı bir şeyi atmak anlamında kullandığında, bazen kendisi bir şeyi atmak istediğinde bu kullanım "bunu atıyorum, atmak istiyorum, atayım mı" gibi anlamlara gelebiliyorken, bazen bizim bir şeyi atmamızı istediğinde bu kullanım "onu at, onu bana at, atmanı istiyorum, atacak mısın" gibi anlamlara gelebiliyor. Üçüncü şahıslar söz konusu olduğunda bu kullanım "atsın, atsınlar" anlamına geliyor. Diğer yandan annesi Kürtçe "bavêj" (at) dediğinde bunu anlyyor ve elindekini atarken "at" diye sesleniyor. Tüm bu kullanım alanı, onun top, balon veya herhangi bir nesnenin firlatılmasına gönderme yapmaktadır. Diğer yandan elimizdeki bir şeyi kendisine vermemizi istediğinde "at" kelimesini "ver" anlamında kullanıyor. Yerine göre "ver" anlamında, yerine göre "bırak" anlamında oluyor bu kullanım. Bir diğer kullanım, yine bir şeyi atmak anlamında; fakat bu defa bir şeyi, delikli bir kutunun deliğinden içeriye bırakmak şeklindeki bir atmak kastediliyor. Üzerinde delik olan oyuncaklar ya da içi boş bidonlar bu kullanıma elverişli alanlar. Çöpü çöp kutusuna atmak da buna dahil. Çöpü çöp sepetine atmaktan hareketle, atılması gereken, çöp değerinde olan her şey "at" kelimesiyle ifade ediliyor. Bu defa "at", fiil değil de isim olarak kullanılıyor. Bu, atılacak eski bebek bezi, yerdeki bir kağıt parçası veya herhangi bir nesne olabileceği gibi, tüm çöp sepetleri de aynı şekilde "at" olmaktadır. Nesnelerin bir şeyin içine atılmasından çöpün atılmasına oradan çöp sepetleri ve çöp kutularına kadar sirayet eden "at" kelimesi, çöp arabasına da ulaşıyor. Mesela evde oturuyoruz, sokağa giren çöp kamyonunun sesi bariz bir şekilde belli oluyor, parmağıyla işaret edip "at" diyor, yani "çöp arabası geldi" demek istiyor. Tabi bu kullanımın buraya uygun düştüğünü anlaması, bizim "çöpü atmak" ifademiz ile "çöp arabası" ifademizin birleştirilmesinden doğuyor. Aynı şekilde delikli nesnelerden içeri bir şeyi attı̆̆ımız için, yeni bir kelime bulununcaya kadar

94 Noam Chomsky, Syntactic Structures, 14th ed., Paris, Mouton Publishers The Hague, 1985, s. 13 . 
delikler için de "at" kelimesi kullanılacak anlaşılan. Başka bir kullanımda bu kelime "pis" anlamına geliyor. Yerden eline alıp ağzına götürdüğü zararlı bir şey olduğunda onu atmasını istediğimiz için "pis" olan şeyler artık "at" kelimesiyle karşılanmaya başlıyor. Nesnelerin bu şekilde adlandırılmasına "top, balon" gibi nesneler de dahil oluyor. Yani oynarken "at" dediğimiz top, balon ve benzeri şeyler "at" olarak adlandırılıyor. Örneğin çekyatın altına kaçmış küçük bir top var, eğilip ona bakıyor, eliyle işaret ederek "at" diyor, "orada bir top var" ya da "o topu bana ver" demek istiyor o esnada. "Atlamak" fiilinin ilk hecesinin de "at" olduğunu öğrenmesi, yükseğe çıkıp atlama idmanlarında işine yarıyor. Bir kutunun veya minderin üzerine çıkıp "at" diye seslendiğinde, "bakın şimdi buradan atlayacağım" demek istiyor. Tüm bu kullanımlar "at" ortak sesinde buluşmakla birlikte "atmak" fiilinin etrafinda dönen bir anlam yelpazesinin alanında bulunması itibariyle mantıksal düşünmenin başladığı noktada düşündüğünü mantıksal bir dil aracıllı̆̆yla ifade etmenin de ilk göstergeleridir. Ancak bu kelime bir kez öğrenilince, atmak fiilinden uzak eş sesli başka bir kelimenin öğrenilmesi de zor olmuyor tabi. Mesela resim ve fotoğraflardan aşina olduğu hayvanı artık nerede olsa tanıyor, apartmanın girişindeki at resminden, kitaplardaki at fotoğraflarına kadar her nerede ve ne zaman o hayvanı görse "at" diye sesleniyor. Dahası, bir şeye ata biner gibi bindiğinde "at" diyor. Bunu ekrandan değil bizden kapmıştı. Ayaklarıma çıkıp da ata biner gibi oturunca "at" diyor, ardından "dıgıd dıgıd" da demeye çalışıyor hemen. Belki de "hadi atçlık oynayalım" demek istiyordur. Böylece mantıksal düşünme, düşündüğünü mantıksal bir dile dökme halkas1 genişliyor. Bunların dışında daha birçok şey için "at" diyor aslında, fakat bu şeyleri biz bazen anlamakta zorlanıyoruz. Biz anlamakta zorlanınca o da bu tür kullanımları azaltıyor sanırım. Çünkü dil, iletişim için kullanılır, iletişimde işe yaramayınca da bazı kullanımlar terk edilmeye başlanır doğal olarak.

Aynı şeyi örneğin “af” (av/su) kullanımı için de gözleyebiliyoruz. Ben "su içmek ister misin" şeklinde Türkçe bir cümleyle soru sorduğumda, "af" diyerek su içmek istediğini vurguluyor. Yine mesela eline içi boş bir kap alıp "af” dediğinde, "bunun içine su koymak istiyorum" demek istediğini biz anlıyoruz. Yine konuşmasını süsleyen diğer tek heceli kelimelere örnek vermek gerekirse; anne'nin kısaltılmışı “an”, okuma'nın kısa hali “ok”, ayak'ın ya da ayakkabı'nın kısa hali "ak" bunların başında geliyor. "An" sadece anneye seslenirken söylenmekle kalmıyor, aynı zamanda "bunlar annenin elbiseleri”, "bu annenin diş firçası", "annem de gelip dişlerini firçalasın" gibi anlamlara da geliyor. İlk anda bu bizim yakıştırmamız gibi gelebilir, ancak çocuk "diş firçası" dediğimizde veya "çorap" dediğimizde rahatlıkla anlıyorsa ve babanın değil de annenin çorabını gördügünde "an" diyorsa, bu kelimeyi tek kelime olarak görmekle yetinmek yanlış olur, 
o yüzden bu seslenişin ardındaki cümleyi biz burada önemsiyoruz ki ebeveynler de zaten bunu hemen anlıyorlar. "Ak" (ayak, ayakkabı) kelimesini önemsemesi, hem bazen ayağıyla oynaması hem de çorabını giymesi ya da dışarı çıkarken ayakkabısını giymesi gibi etkinlikler sebebiyle bir ihtiyaç ve bir meraktan kaynaklanıyor olabilir. Konuşmalarımızın yanı sıra, şapkasını ve montunu giydiği zaman dışarı çıkacağını anlıyor ve "ak" diyor, bu da "şimdi sıra ayakkabıda" gibi anlaşılabilir mesela. "Ok" kelimesi "okumak" ve "kitap" anlamlarına geldiği gibi "hadi şimdi kitap okuyalım, bana hikâye okur musun" gibi anlamlara da geliyor. Daha da ileri giderek şunu söyleyebiliriz ki, dikkatli ebeveynler çocuğun gün içinde seslediği çoğu şeyin mutlaka bir anlamı olduğunu düşünürler. Örneğin bir keresinde askıdan onun minik elbiselerini topluyordum, bir elbisesini çekiştirip "don" dedi, ilkin pek önemsemedim, sonra düşündüm, elbise türü anlamındaki don kelimesini biz kullanmıyorduk, acaba bununla neyi kastetmişti? Katlayıp kaldırdığım elbiseyi tekrar elime aldığımda üzerinde dinozor resimlerinin olduğunu görmüştüm. Bizim konuşmalarımızdan kapmıştı bu kelimeyi. Dinozor'un kısaltması olan "don"du demek istediği. "İşse dinazorlu elbise" demek istiyordu. Bu da gösteriyor ki biz anlamasak da 12-13 aylık bu çocuk gün içinde seslediği bazı kelimeleriyle aslında zihnindeki duygu ve düşünceleri dile getiriyor, bazen de oyun amaçlı bu kelimeleri gün içinde tekrarlıyor ki bu da hem onu eğlendiriyor hem de söz konusu kelimelerin yerleşik hale gelmesine sebep oluyor.

\section{Çocuğun Tek Kelimesinden Onun Hayal Dünyasına}

$\mathrm{Bu}$ dönemdeki çocuğun tek kelimelik konuşmalarından hareketle onun düşünce dünyasına geçmeye çalıştık. Ancak eğer onun hayal dünyasına daha yakından bakacak olsak, yorumlarımızın ve düz cümlelerimizin ne kadar yetersiz olduğunu görürdük. Çünkü kelimelerin arkasındaki cümleleri keşfetmeye çalışırken yetişkinlerin daraltılmış mantığıyla düşünüyoruz. Oysa çocukların daha özgür ve sınırları daha geniş düşüncesine bu aylardan itibaren vakıf olabilseydik bambaşka cümleler çıkabilirdi karşımıza. Hatta az da olsa bazen bunu yakalayabiliyoruz. Örneğin yemek yerken sokaktaki köpeği hatırlayan Hikmet Roni, yemekten ona da vermemizi istiyor, bu esnada "hav hav" demesi, "yemekten ona da ver" ya da "önce ona ver" anlamına geliyor, çünkü biz kaşığı pencereye doğru uzatıp verir gibi yapmadıkça kendisinin yemeği kabul etmediğini görüyoruz. Ya da "ka" diyerek oyuncak kaplumbağaya yemek yedirmemizi istiyor, sonra kendi de yiyor. Burada "ka" kelimesi "önce kaplumbağaya ver" şeklinde anlaşılmalı.

Çocuğun hayal dünyası, sınırları olmayan özgür bir dünya olduğu için, düşündükleri ve söyledikleri şeyler yetişkinlere komik ve bazen de saçma görünebilir. Yine biz çocuğun bir şeyleri beceremediğini zannederiz, mesela bize göre 
çocuk üçgen şeklindeki nesneyi yuvarlak yerden içeri atamayacağını bilmez ama atmaya çalışır, atamayınca ağlar; ancak bu gibi durumlara bir de onun zihin dünyasının daha özgür ve sınırsız olduğunu düşünerek baksak, daha farklı sonuçlara ulaşırız. Dolayısıyla ilk sözcük döneminde çocuğun telaffuz ettiği kelimelerin cümleye çevrilişinde şimdiye kadar yapılan çalışmaların da yeniden gözden geçirilerek çocuğun hayal dünyasına göre yeniden düşünülmesi gerekiyor. Bizim örneğimizde, Hikmet Roni'nin, yeni aldığı ayakkabılarını dışarda gördüğü ilk kediye göstererek “ak, ak!" demesini nasıl anlayacağız mesela? Elinde yeterli miktarda araç (kelimeler) olsayd1, zihnindekini nasıl ifade edecekti? Kedinin karşısında öylece durup parmağıyla ayakkabılarını göstererek söylediği "ak" kelimesi birçok derin yapı eşliğinde yorumlanabilir. Belki yetişkinlerin şiir dediği şey de buradan çıkar ya da en azından bundan bir pay alır.

\section{Kelimeler Arasında Geçiş ve Kelimeyi Tamamlama}

Tek heceli bu kelimelerin aynı zamanda farklı anlamlardaki uzun kelimelerin içinde yer alan bir heceyi de teşkil etmesi, çocuğun hem o kelimelere geçmesini kolaylaştırıyor hem de ebeveynler dikkatli olduğunda bu hecelerle çocuk o uzun isimli nesne veya kavramlara da gönderme yapıyor. Örneğin Hikmet Roni “at”"1n yukarıda bahsi geçen kullanımlarının yanı sıra "hatırlamak, saat, rahat" gibi kelimelerin içinde de ses olarak yer alması, bu kelimeleri kullandığımızda onun "at" hecesini hemen tekrarlamasına yol açıyor. Bunlardan hatırlamak ve rahat gibi daha soyut olanlarını kullanamasa da, kol saati için "at" demeyi öğreniyor şimdilik.

Benzer seslerden oluşan kelimelerden aynı iki veya üç harfi yontup alarak kullanması, bir kere kullanmaya alıştığı bir heceyi/kelimeyi başka bir şey için de kullanarak konuşma dilini genişletmesini sağlıyor. Mesela ayakkabı anlamındaki "ak" kelimesini pratikte kullandıktan sonra şapka kelimesinde de aynı harflerin yer alması şapkaya da "ak" denilebileceğini ona sezdiriyor, ancak kendisinden bir "h" ilave ederek "hak" diye adlandırıyor şapkayı. Daha sonra "k" harfi etrafında dönen benzer kelimeler üretebiliyor, "ok" (okumak) gibi. "At" kelimesini kullandıktan sonra ütü için "ot" (bazen de "öt") demesi veya yine oturmak için "ot" demesi (ikisi arasında tonaj-vurgu farkları var) buna başka bir örnektir. "Hêk" (yumurta) kelimesini kullandiktan sonra benzer seslere sahip "nok" (nohut) kelimesine kolay bir şekilde geçiş yapmasını da buna bağlayabiliriz. Tabi, evde nohudun ilgi çekici bir nesne olarak karşısına çıkmış olmasını da buna eklemeliyiz.

Bunlar kelimeler arasındaki ses benzerlikleriyle ilgilidir. Ayrıca "at" kelimesinin hem atmak fiili hem de at hayvanı için kullanılması, işini kolaylaştırmış oluyor. Bu sayede kullandığı kelimeleri artırmış oluyor çünkü. 
Burada ayrıca çocuğun bir kelimeyi bırakıp yeni bir kelimeye geçmesinden bahsedebiliriz. 13. ayın sonlarına kadar top ve balon için "at" kelimesini kullanan Hikmet Roni, 14. aydan itibaren topu ve balonu kendi adıyla adlandırmaya başladı ve top'a "dot" demeyi (tersten okunuşu + bir harf değişikliği) balon'a ise "bam" demeyi (ilk iki harf + patlama sesi) yeğledi. El ele tutma eylemindeki "tut" kelimesini biliyor olması da top'a "dot" demesine yardımcı olmuş olabilir. Böylece 14. ayın başlangıcından itibaren her gün konuşma halkasını daha da genişleten çocuğun sürekli yeni denemeler yaptığını gözlemeye başladık. Bu ilerleme bir insanın tümüyle ihata edemeyeceği çapta geniş ve hareketli bir süreçti. Covid-19 salgını sebebiyle evde daha fazla zaman geçirmemiz onunla aramızda gerçekleşen iletişimi daha samimi ve üretken bir havaya sokmuştu.

Tam bu süreçte gözlenebilen bir başka değişim de tek heceye indirgenen kelimelerin bir sonraki merhalede iki heceye çıkarılarak tamamlanmasıdır. Örneğin Hikmet Roni bu aylarda "an" ve "bap" şeklinde kullandığ kelimeleri 14. aydan itibaren "anne" ve "baba" şeklinde tamamlayarak dil gelişimini sürdürdü. Bu da dil edinim sürecinin fizyolojik gelişime paralel olarak ilerlediğini gösteriyor.

\section{Sonuç}

Ortalama 12. ayda başladığını söyleyebileceğimiz tek sözcük dönemiyle birlikte çocuk, zihnindeki düşünceleri tek kelimeden oluşan bir ifade biçimiyle dile getirmeye başlamaktadır. Anne karnından itibaren başlayan "duyma, anlama, ayırt etme" şeklindeki dil süreci, doğumdan itibaren ağlayarak ve belli sesler ç1kararak kendini dışa vurmaya başlar, daha sonra işaret dili ve ses taklitleri gelir, ardından da tek sözcük dönemi. Buna göre, çeşitli tasniflerde kullanılan "dil öncesi dönemi”nin yanlış bir kullanım olduğunu söylemek durumundayız. Çünkü bu ifade tıpk1 "yürüme öncesi dönem"i kastetmek üzere "ayak öncesi dönem" demeye benzer. Dil hem ağızdaki organ hem beyindeki merkez hem de zihinsel mevcudiyet olarak insanda doğuştan var olan bir özelliktir, o halde "dil öncesi dönem" demek yerine "konuşma öncesi dönem" demek daha doğrudur.

Tek sözcük döneminden itibaren somut bir şekilde konuşmaya başlayan çocuk, ne bir makinedir ne de hayvanlarla aynı doğaya sahip bir canlı; aksine o kendisine mantıklı düşünme ve bu düşüncelerini dil aracılığıyla aşikâr etme yeteneği verilmiş farklı bir canlıdır. Bu yüzden onun dilsel ifadelerini sadece betimleyici bir dilbilimsel yöntemle aktarıp bunun ötesine geçmemek, onu anlama noktasında eksik kalmak demektir. Burada yapılması gereken şey, onun tek kelime aracılığıyla anlatmak istediği şeyi anlamak ve bu kelimenin temsil ettiği cümleyi mümkün olduğunca ortaya çıkarmaya çalışmaktır. Bu da açıklayıcı ve yorumlayıcı bir dilbilimsel yöntemi gerektirmektedir. 
Bebek doğuştan itibaren iki veya daha fazla dili edinebilecek kabiliyetle donatılmıştır. Hikmet Roni örneğinde gördüğümüz üzere çocuk tek sözcük döneminde (12. ve 13. aylar) fizyolojik gelişimine paralel bir şekilde her iki dili de edinmeye başlamıştır. Bu noktada anlama (alıcı dil) düzeyindeki ediniminin konuşma (ifade edici dil) düzeyindeki ediniminden daha kapsamlı olduğu görülmektedir. $\mathrm{Bu}$ aylarda çocuk her iki dili de anlamakta, konuşurken ise kolay telaffuz edebildiği bir kelimeyi seçip onunla meramını ifade etmektedir. Bir kavrama karşılık gelen bu kelimeyi bazen Kürtçeden bazen de Türkçeden seçtiği, kimi zamansa her iki dildeki kavramı da kullandığı gözlenmektedir.

Dil ediniminin belli bir iletişim içinde gerçekleştiğini söylemek, yanlış anlaşılmaya meydan vermemek için açıklanması gereken bir ifadedir. Burada iletişim dediğimiz şey, bir öğretme olmadığı gibi bir programlama da değildir. Aksine hayatın doğal akışı içinde çocuk çevresindekilerin dilini kolayca edinir ve konuşmaya başlar. Bunun için özel bir çaba harcamaya veya endişe duymaya gerek olmadığı açıktır. Tek sözcük dönemindeki iletişim de ebeveynin günlük hayatındaki doğal faaliyetlerinden oluşmaktadır. İki dilliliğin edinilmesi ise bizim örneğimizde annenin çocukla Kürtçe babanınsa Türkçe konuşması neticesinde gerçekleşmektedir.

Tek sözcük döneminde tercih edilen kelimeler çocuğun fizyolojik gelişimine uygun olan seslerden oluşur ve çoğunlukla tek hecelidirler. Bu aylarda çocuk, uzun cümlelerle anlatılacak bir düşünceyi tek bir kelime ile ifade etmeyi başarır. $\mathrm{Bu}$ bazen bir ihtiyaçtan kaynaklanan bir iletişim eylemi, bazen bir duygu dişa vurumu, bazense bir melodi olur. Çocuğun bu tek kelimesini derinliği olan yüzeysel bir yapı olarak görecek olursak, onun arkasındaki anlamsal içeriğin derin bir yapıyı teşkil ettiğini fark etmek zor olmayacaktır. Bu derin yapı çoğu zaman ebeveyne yöneltilmiş bir talep olmakla aslında bir inşâ faaliyeti olarak da görülebilir. Dilbilimcinin çabası bu eksiltili ifadeleri yorumlayıp tamamlamayı denemek şeklinde kendini gösterecektir. Ebeveynlerin günlük hayatta yaptığı şeyi dilbilimsel düzlemde açılığa kavuşturmak, aynı zamanda çocuğun zihnine ve belki de hayal dünyasına bir kapı aralayacaktır. Hiç şüphesiz çocuğun tek bir kelimesinden hareketle onun zihin dünyasını çözmek imkansızdır, ancak böyle bir gayret içine girmek dilbilimden psikolojiye, tıptan pedagojiye kadar birçok alanda insanın tabiatına yönelik yaklaşımlara yeni bir soluk getirecektir. 


\section{Kaynakça}

Aksoy, A. Belgin - Aksoy, Merve, "Yürüme Döneminde Küçük Konuşmacılar: Gelişimsel Bir Bakış", Erken Çocukluk Çalışmaları Dergisi, cilt 4, sayı 1, Mart 2020.

Alpöge, Gülçin, “Çift Dilli Çocukların Dil Gelişimi”, Turkophone, cilt 1, say1 $1,2014$.

Aşıc1, Murat, Ailede Dil Etkinlikleri, İstanbul, Morpa Kültür Yayınları, 2003.

Atli, Mehmet Halit, "Çokdillilik ve Çokdilli Beyin", Uluslararası Sosyal Araştırmalar Dergisi, cilt 11, say1 60, 2018.

Austin, J. L., Söylemek ve Yapmak, çev. Levent Aysever, İstanbul, Metis, 2009.

Baştürk, Mehmet, Anadil Edinimi, 2. bs. Ankara, Pegem Akademi, 2013.

Bingöl, Abdulkuddûs, "İletişim Bağlamında Mantık ve Dil”, Ankara Üniversitesi İlahiyat Fakültesi Dergisi, cilt XL, 1999.

Canan, Nağme, "Okul Öncesi Dönem Çocuklarda İki Dilliliğin Zihin Kuramı Gelişimi Üzerine Etkisi”, (Yayımlanmamış Yüksek Lisans Tezi), Maltepe Üniversitesi Sosyal Bilimleri Enstitüsü, İstanbul, 2012.

Chilla, Solveig - Fox-Boyer, Annette, İkidillilik/Çokdillilik, çev. Ezel Babur, Idstein, Schulz-Kirchner Verlag Gm, 2010.

Chomsky, Noam, Bilgi Sorunları ve Dil: Managua Dersleri, çev. Veysel K11ıç, İstanbul, Bgst Yayınları, 2009.

, Dil ve Zihin, çev. Ahmet Kocaman, 3. bs., Ankara, Bilgesu Yayınc1lik, 2018.

, Dil ve Zihin Incelemelerinde Yeni Ufuklar, çev. F. Burak Aydar, İstanbul, Boğaziçi Üniversitesi Yayınevi, 2019.

, Dilin Mimarisi, çev. İsa Kerem Bayırlı, İstanbul, Boğaziçi Üniversitesi Yayınevi, 2014.

, Syntactic Structures, 14th ed., Paris, Mouton Publishers The Hague, 1985.

Corballis, Michael C., İşaretten Konuşmaya Dilin Kökeni ve Gelişimi, çev. Aybek Görey, İstanbul, Kitap Yayınevi, 2003.

Cürcânî, Abdulkahir, Delâilu'l-i 'câz, tahkik M. Muhammed Şakir, Kahire, Mektebetü'l-Hânci, 1984. 
Çakır, Turan, "Çocukta Dil Gelişimi ve Kuramsal Yaklaşımlar", Sakarya Üniversitesi Eğitim Fakültesi Dergisi, cilt 0, sayı 7, 2013.

DeCasper, Anthony J. - Fifer, William P., "Of human bonding: Newborns prefer their mother's voices", Science Science, vol 208, issue 4448, 1980.

Durusoy, Ali, "Mantık ve Dil”, Yakın Doğu Üniversitesi İslam Tetkikleri Merkezi Dergisi, y1l 6, cilt 6, sayı 1, 2020.

Emiroğlu, İbrahim, "Mantık", Türkiye Diyanet Vakfi İslâm Ansiklopedisi (DIA), cilt 28, İstanbul, TDV Yayınları, 2003.

Farabi, Ebu Nasr, İhsâu'l- ‘ulûm, tahkik Osman M. Emin, Mısır, Matbaatu's-Saade, 1931.

Gazali, Ebu Hâmid, el-Me ârifu'l-'akliyye, tahkik Abdulkerim Osman, D1maşk, Dâru'l-Fikr, 1963.

Güvendir, Emre - Yıldız, I. Gamze, Dil Edinimi, Ankara, Anı Yayınc1lık, 2014.

İbn Cinnî, Ebu'l-Feth Osman, el-Hasâis, tahkik Muhammed Ali en-Neccâr, 3 cilt, Beyrut, el-Mektebetu'l-İlmiyye, 1952 (girişteki tarih).

Kara, Şeref, “Ana Dil Edinimi ve Erken Yaşta Yabancı Dil Öğretimi”, Uludă̆ Üniversitesi Eğitim Fakültesi Dergisi, cilt 17, sayı 2, 2004.

Karacan, Elvan, "Bebeklerde ve Çocuklarda Dil Gelişimi", Klinik Psikiyatri, cilt 3, say1 4, 2000.

Karademir, Fevzi (ve diğerleri), Sözlük/Ferheng: Kürtçe-Türkçe \& Türkçe-Kürtçe, Ankara, Türk Dil Kurumu Yayınları, 2014.

Karaman, Yahya - Bozbay, Fatih, "Lisan Fonksiyonlarının Gelişimi ve Lisanı Etkileyebilecek Bozukluklar”, Erciyes Tip Dergisi, cilt 17, sayı 1, 1995.

Kazvînî, el-Hatîb, Telhîsu'l-miftâh, Karaçi, Mektebetu'l-Buşrâ, 2010.

Keklik, Saadettin, Çocukta Dil Edinimi, Ankara, Türk Dil Kurumu Yayınları, 2015.

Koç, Ayhan Aksu - Kertez, F. Nihan, "Anadili Gelişimi”, Aklın Çocuk Hali, (içinde), der. Çağla Aydın ve diğerleri, 3. bs., İstanbul, Koç Üniversitesi Yayınlar1, 2020.

Kol, Suat, "Erken Çocuklukta Bilişsel Gelişim ve Dil Gelişimi", Sakarya Üniversitesi Eğitim Fakültesi Dergisi, sayı 21, May1s 2011.

Korkmaz, Zeynep, Gramer Terimleri Sözlüğ̈̈, 2. bs., Ankara, Türk Dil Kurumu Yayınları, 2003. 
Özbaydar, B., "12-24 Ay Arasında Dil Gelişmesi”, Psikoloji Çalı̧̧maları, cilt 8, say1 0, 2012.

Özge, Duygu, “Çocuklarda Dil Anlama Süreçleri”, Aklın Çocuk Hali, (içinde), der. Çağla Aydın ve diğerleri, 3. bs., İstanbul, Koç Üniversitesi Yayınları, 2020.

Özpolat, Murat - Sağlam, Mehmet, "Erken Çocukluk Döneminde İki Dilliliğin Çocukların Alıcı ve İfade Edici Dil Gelişimine Etkisinin İncelenmesi”, Erken Çocukluk Çalışmaları Dergisi, cilt 4, sayı 3, 2020.

Özüdoğru, Murat - Dilman, Hakan, Anadil Edinimi ve Yabancı Dil Öğrenim Kuramları, Ankara, Anı Yayıncılık, 2014.

Pinker, Steven, Dil İçgüdüsü: Zihin Dili Nasıl Meydana Getirir, çev. Feray İlgün, İstanbul, Bilge Kültür Sanat, 2018.

Rousseau, Jean-Jacques, Émile, çev. Yaşar Avunç, 9. bs., İstanbul, Türkiye İş Bankası Kültür Yayınları, 2017.

Savaş, Bekir, Okuma Eğitimi ve Çocuklarda Dil Gelişimi, İstanbul, Papatya Yayınc1lik, 2018.

Saygı1l, Sefa, Çocuk Psikolojisi, İstanbul, Nesil, 2018.

Searle, John R., Bilinç ve Dil, çev. Muhittin Macit - Cüneyt Özpilavcı, 2. bs., İstanbul, Litera Yayınc1lık, 2016.

, Söz Edimleri, çev. Levent Aysever, Ankara, Ayraç, 2000.

Litera Yayınc1lık, 2015.

, Zihin Dil ve Toplum, çev. Alaattin Tural, 2. bs., İstanbul,

Topbaş, Seyhun, "Sesbilgisi Açısından Dil Edinim Süreci”, Dilbilim Araştırmaları Dergisi, sayı 7, 1996.

Türker, Sadık, "Fârâbî'de Dil ve Mantık İlişkisi”, Kutadgubilig Felsefe-Bilim Araştırmaları, sayı 1, 2002.

Uzundağ, Berna A. - Küntay, Aylin C., "İkidillilik Gelişen Zihni Farklı Şekillendirir mi?", Aklın Çocuk Hali, (içinde), der. Çağla Aydın ve diğerleri, 3. bs., İstanbul, Koç Üniversitesi Yayınları, 2020.

Vendryes, J.V., Dil ve Düşünce, çev. Berke Vardar, İstanbul, Multilingual, 2001.

Vygotsky, L.S., Düşünce ve Dil, çev. Semih Koray, İstanbul, Kaynak Yayınlar1, 1985.

Yapıc1, Şenay, "Çocukta Dil Gelişimi”, Journal of Human Sciences, cilt 1, sayı 1, 2004.

Yavuzer, Haluk, Çocuğunuzun İlk 6 Yllı, İstanbul, Remzi Kitabevi, 1997. 